\title{
Epigenetics: A Key to Comprehending Biotic and Abiotic Stress Tolerance
}

\section{in Family Poaceae}

\author{
Veerala Priyanka ${ }^{1}$, Neha Goel ${ }^{2}$, Inderpreet Dhaliwal ${ }^{3}$, Mohit Sharma ${ }^{4}$, Rahul Kumar ${ }^{1}$ and Prashant Kaushik ${ }^{5}{ }^{*}$ \\ ${ }^{1}$ Department of Genetics and Plant Breeding, Sardar Vallabhbhai Patel University of Agriculture and Technology, \\ Meerut 250110, India; veeralapriyanka@gmail.com (V.P.); rahul.gujjar.3009@gmail.com (R.K.) \\ ${ }^{2}$ Division of Genetics and Tree Improvement, Forest Research Institute, Dehradun, Uttarakhand, India; \\ nehagoel24march@gmail.com \\ ${ }^{3}$ Department of Plant Breeding and Genetics, Punjab Agricultural University, Ludhiana 141004, India; \\ dhaliwalinderpreet@gmail.com \\ ${ }^{4}$ Malopolska Centre of Biotechnology, Karakow, Poland and University of Warsaw, Warsaw Poland (M.S.); \\ ksmohit@gmail.com \\ ${ }^{5}$ Instituto de Conservacióny Mejora de la Agrodiversidad Valenciana, Universitat Politècnica de València, 46022 \\ Valencia, Spain \\ *Correspondence: prakau@doctor.upv.es
}

\begin{abstract}
Climate change has had a significant impact on many ecosystems around the world, prompting native population species to adapt to the current weather patterns eventually. Pre-existing genetic variation in populations explains part of this adaptation. Still, recent studies have shown that new stable phenotypes can be generated through epigenetic modifications in just a few generations, thereby contributing to the stability and survival of plants in their natural habitat as they eventually adjust to the surrounding impacts. The state of chromatin inside plant cells varies, allowing cells to fine-tune their transcriptional profiles to better adapt to stimuli from the external environment. Within a cell, chromatin state changes such as post-transcriptional histone modifications and variations, DNA methylation, and non-coding RNA activity are all examples of chromatin state alterations that may epigenetically dictate certain transcriptional outputs. Recent advances in the field of 'Omics' in major crops has made it easier to identify epigenetic changes and their impact on plant responses to environmental stresses. These epigenetic mechanisms thus play an important role in improving crop adaptation and resilience to changing environments, and this variation that has emerged can thus be exploited in crop breeding, ultimately leading to the generation of stable climate-resilient genotypes.
\end{abstract}

Keywords: epigenetics, epigenetic variation, chromatin changes, omics, climateresilient crops

\section{Introduction}

Family Poaceae (formerly known as Gramineae) comprises monocotyledonous flowering plants and ranks among the top five flowering plant families. Domesticated cereal crops like wheat, corn, rice, barley, millets, and other species often used to nourish livestock and poultry, pertain to one of the most important plant families on the world. These cereal crops provide just over half (51\%) of all the human dietary energy requirements [ 1 ]. Members of the Poaceae family are most vulnerable to both biotic and abiotic stresses. Insect pests, fungi, bacteria, viruses, drought, cold, heat, salinity are respectively the biotic and abiotic stresses affecting the crops [ 2 ]. Different crops respond differently 
to various abiotic stresses: wheat and rice are sensitive to water scarcity and soil salinity, leading to severe yield reductions. At the same time, barley seems to have an innate drought and salinity tolerance. Stress is inevitable in the life cycle of living organisms. Plants, however, are sessile organisms that have evolved sophisticated gene regulation mechanisms to ensure their survival in the changing environment [3 ]. Stressful conditions generally do not occur as isolated events but as crosstalk of multiple stresses. These mechanisms entail genes linked to a number of interconnected pathways that lead to improved stress tolerance [4 ].

In response to stress, plants change their morphological traits, physiology, and other characteristics. They detect environmental changes and transmit the altered environment signals through a signal transduction cascade [ 5, 6 ], resulting in the accumulation of transcription factors that activate gene expression and allow the adaptation of plants to environmental challenges [7]. Depending upon whether the stress is permanent or transitory, plants respond through various short term and long-term strategies. Short term strategies include alteration in the plant homeostasis. Long-term strategies include transgenerational changes involving the development of heritable gene expression changes. This consists of creating new epigenetic marks while erasing old ones, as well as the increased expression of some genes while silencing the expression of others. Thus, epigenetic regulation is also one kind of the important mechanism for gene regulation in response to stress. Severe and prolonged stress can lead to genome alterations which may sometimes contribute towards better adaptation [8].

The DNA sequence contains the basic information that guides plant behaviour, and changes in DNA sequence caused by mutation or genetic recombination result in new alleles that may confer enhanced stress tolerance to the plant. However, the rate of formation of new gene combinations is too slow compared to the occurrence of different stresses in the environment [ 9 ]. Thus, the survival of the plant under these conditions is highly dependent on the regulation of a number of stress-responsive genes, or epigenetic mechanisms. The growing understanding of epigenetic regulation in response to environmental stimuli has sparked interest in the role of epigenetics in crop hardiness to abiotic stress, with an emphasis on the Arabidopsis thaliana plant species [ 10 ]. Drought also has a major impact on crop yield; however, it has been demonstrated that the severity of the stress depends on the phenological status of the plant [11, 22 ]. Impact of extreme heat waves has been analysed in wheat [ 13 ], rice [14 ] and maize [15 ]. Because the effects of stresses on crops are variable and complex, especially when crops are confronted with various stresses, breeding crop varieties for environmental stresses is a slow and challenging process. [16 ]. Recognizing this gap, this review paper provides a detailed overview of epigenetics involvement in abiotic and biotic stress tolerance in Poaceae.

\section{What is Epigenetics?}

Aristotle, in his book "On the Generation of Animals", first described the phenomenon of epigenetics to distinguish the unfolding development of an organism from "preformationism". The phenomenon was first studied by Conrad H. Waddington and Ernst Hadorn, and in 1942, Waddington coined the term "Epigenetics", which has been derived from two words "epi", a Greek prefix meaning "on top of"/"in addition to"/"near" and "genetics", to describe how genes interact with the environment to produce a phenotype. Epigenetics, thus, refers to the phenomenon of genetically identical cells or organisms expressing their genomes differently, resulting in phenotypic differences. It is a 
modification of gene expression without a change in DNA sequence and is potentially stable and heritable [ 17 ].

However, sometimes such changes can even be harmful, such as the development of cancers. Epigenetic reprogramming in response to various environmental challenges contributes to phenotypic diversity as well as resistance to these challenges [ $18 ; 19]$. The three important epigenetic modifications currently known for initiating and maintaining epigenetic change are DNA methylation, histone modification, and non-coding RNA (ncRNA)-associated gene silencing (Inhibition of RNA) [ 20 ] Stress acts as a stimulus, changing genic expression levels through a variety of mechanisms including DNA methylation, histone modifications, and RNA interference [21]. Studies of epigenetic responses to various stresses can help us better to understand plant stress adaptation and the mechanisms that underpin it for betterment of crop cultivars. Some stress-induced changes are reverted to their baseline state; however, some of these changes are stable and heritable, named epigenetic "stress memory" [ 22- 25). The knowledge of stress memories can increase our understanding with regard to the adaptation of plants to stresses. Thus, from the last two decades, epigenetics has become a rapidly evolving branch. The role of epigenetics in a variety of stress responses is constantly being discovered through new and ongoing research.

\section{Mechanism of an Epigenetic process}

The mechanism of an epigenetic process can be divided into 3 stages:

i. Epigenator: It is a trigger (food/toxins/radiation/hormones etc.) that alters the cells' environment to produce an epigenetic phenotype. Such signals are transient, lasting long enough in the cell environment to initiate the epigenetic process.

ii. Epigenetic initiator: The trigger (epigenator signal) is translated to mediate the epi genetic effect on chromatin. Epigenetic initiator is primed by epigenator, and determines the location on a chromosome where epigenetic state should be established. 


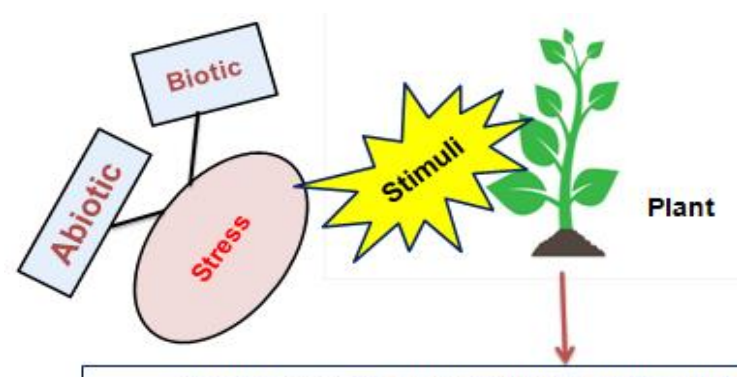

Occurrence of Epigenetic Variation due to stress signals (Through EIS interactions)

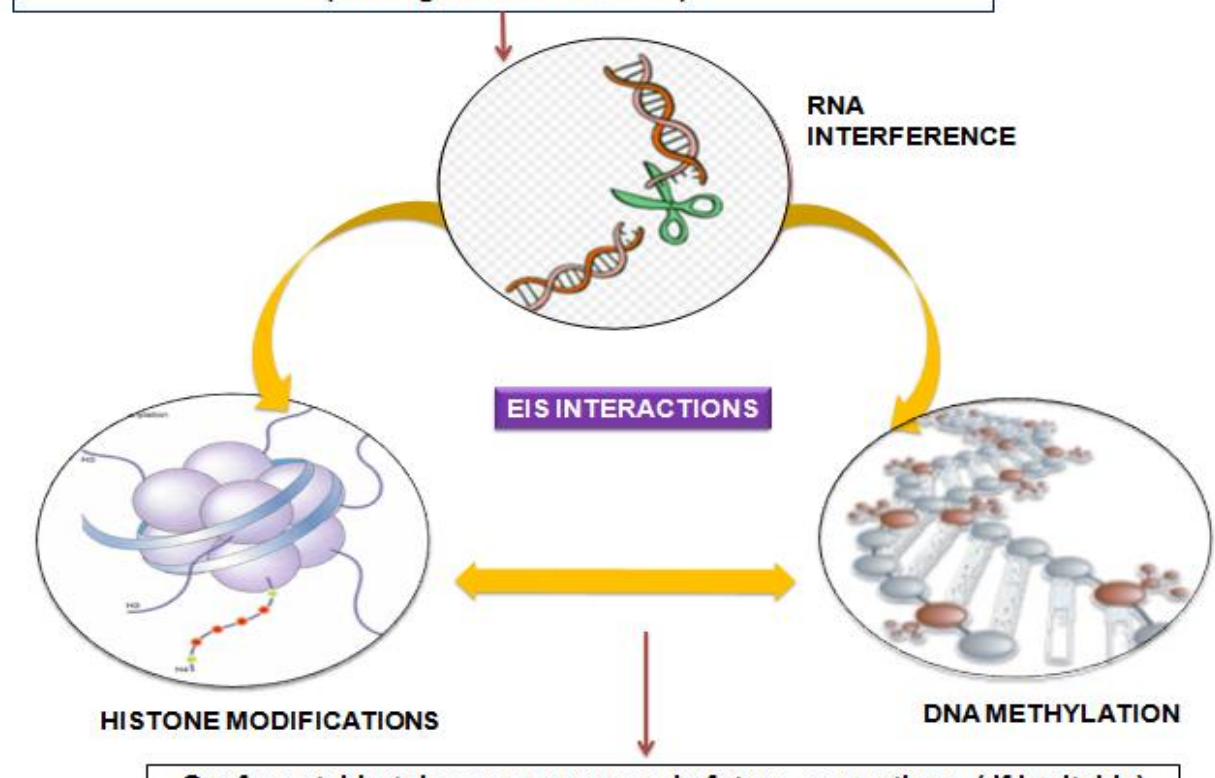

Confers stable tolerance response in future generations ( if heritable)

Figure 1. Schematic representation of the machinery of epigenetic regulation through EIS interactions.

iii. Epigenetic maintainer: The DNA sequence specificity of maintainers is not absolute.

3. Epigenetic Information Systems (EIS): Most of the epigenetic machinery of higher eukaryotes appears to be providing them with cellular and genomic immunity [17 ]. When stress is relieved, most of the stress-induced epigenetic modifications return to their original thresholds; however, some modifications become stable and are passed down through mitotic or even meiotic cell divisions. [ 26 ]. Such stress memories significantly improve the adaptation of plants to that stress also prepare their offspring for future environmental challenges [27; 28]. With the advancement in molecular technologies, our knowledge of the mechanisms of epigenetic responses to environmental stresses is rapidly growing [29]. EIS interactions play an important role by complementing, stabilizing and reinforcing each other through complex interdependent synergy, as shown in figure 1. RNA-RNA hybridisation between siRNA and nascent mRNA also leads to DNA methylation and histone modifications [30]. The 5 methyl Cytosine binding proteins recruit and forms complexes with Histone DeAcetylases (HDACs). In turn, HDACs and histone methyltransferases (MTases) lead to the recruitment of DNA MTases[ 31 ]. Therefore, understanding shared mechanisms contributing to one or more simultaneously occurring stresses has also become an important aspect in crop improvement [32]. 
3.1. DNA Methylation: It is accomplished by attaching a methyl group to the cytosine carbon in the C-p-G dinucleotide sequence [33]. The 5' methylated Cytosine frequently de-aminates to Thiamine, causing mutations. This process is catalyzed by a family of DNA methyltransferases (DNMTs). The C-p-G islands are C-p-G rich areas of 200 bp to several kilobases in length, usually located near the promoters of highly expressed genes. More than $55 \%$ of changes develop clusters. Thus, methylation of C-p-G islands in promoter regions of genes may prevent or deregulate the synthesis of gene products [34; 35]. It also plays an important role in DNA repair, recombination and replication, and regulation of gene activity [36].

Three members of the DNA methyltransferase family can produce methylation either de novo, where unmethylated cytosine residues are methylated (DNMT3a and $3 b$ ) or by maintaining the pre-existing or established methylation patterns following DNA replication (DNMT1) [37;38]. Furthermore, the level and status of DNA methylation might change under stress conditions, such as salt, drought, low temperature, heavy metal, pathogen and so on [39]. DNA methylation analogues also isolated from rice [40] and barley [41]. The methylation levels can be detected by High-Performance Capillary Electrophoresis (HPCE) which measures global methylation level through the quantification of 2'-deoxynucleosides. Detection and quantification of 5-methyl 2'-deoxycytidine in genomic DNA is performed using micellar HPCE with (UV/VIS) Spectrophotometry detection [42]. Demethylation of DNA occurs in two ways in plants: passive demethylation and active demethylation [43;44]

3.2. Histone Modifications: Each and every nucleosome is made up of an octamer of four core histones (H3, H4, H2A, and H2B), with 147 base pairs of DNA wrapped around it [45] Post translational modifications (PTMs) may also occur on the lateral surface of the nucleosome core histones that are in contact with the DNA, referred to as the nucleosome core surface [46]. They mainly occur along the N-terminal tails of the core histone, including acetylation (mainly at Lysine residue), methylation (mainly at Lysine and Arginine residues), phosphorylation (mainly at Serine and Threonine residues), ubiquitination (mainly at Lysine residue) and sumoylation (mainly at Lysine residue) [47-50]. A combination of site-specific posttranslational modifications on different residues of histone tail constitutes "histone code" [51].

The most common and well-studied type of modification is acetylation of lysine residues' amino group [52]. By adding acetyl groups to histone protein tails, the positive charge of histones is decreased, thereby weakening the bond between histone proteins and DNA. This facilitates transcription by increasing the accessibility of DNA to RNA polymerase II. Histone deacetylases (HDACs) deacetylate histone tails in order to acetylate N-terminal lysine residues, thereby increasing DNA-histone interaction and inhibiting transcription [53]. Both HATs and HDACs play important roles in regulating chromatin structures related to gene expression [54]. Additionally, both may also increase or decrease the DNA binding ability of histones resulting in DNA condensation or decondensation, thereby gene inactivation or activation [55]. Histone methyltransferases (HMTs) trimethylate histone $\mathrm{H} 3$ at lysine 4 (H3K4), resulting in an active transcription mark, or dimethylate histone $\mathrm{H} 3$ at lysine 9 (H3K9), resulting in a transcriptional silencing signal. Histone demethylation can be confirmed by Chromatin Immunoprecipitation (ChIP) assays [56]. The role of histone H2A and H2B ubiquitination in regulating transcription initiation, elongation, and silencing has been well-reviewed [57, 58 ]. Ubiquitin is a 76-amino-acid polypeptide that regulates a wide range of activities in the body in a multitude of ways. Depending on the attached amino acid, ubiquitylation on a histone tail can either inhibit or augment gene expression. For sumoylation, the small ubiquitin-related modifier 
(SUMO) family of proteins modifies histone H4, which are around 100 amino acids long and inhibits euchromatic transcription by recruiting histone deacetylase and heterochromatin proteins [59]. Thus, histone modifications may regulate gene expression by regulating chromatin dynamics directly influenced by post-translational modifications of the amino-terminal tails of the histones [60] and result in malfunctions of chromatin structure modifiers [61]. Almost all cellular processes, including transcription, replication, repair, recombination, and chromosome segregation, rely on the precise organization of chromatin. Histone-DNA interactions results in the altered accessibility of specific DNA regions to transcription machinery [62]. Chromatin remodelling factor (CHR), including the SWI/SNF ATPases, the imitation switch (ISWI) ATPases, and the chromodomain and helicase-like domain (CHD) ATPases subfamilies, may play a role in mediating either ATP-dependent chromatin remodelling or post-translational histone modifications. [63]. The ATP-dependent chromatin remodelling complexes could alter nucleosome composition and positioning and thus regulate DNA accessibility and gene expression. Posttranslational histone modifications, on the other hand, may affect nucleosome interactions and thus chromatin compactness and structure [64].

3.3. RNAi (RNA Interference): Andrew fire \& Craig c. Mello shared in 2006 for the discovery of RNAi in Caenorhabditis elegans. The mechanism by which particular segments of double-stranded RNA may prevent the expression of a certain gene with a similar sequence to a dsRNA that is orthologous to the gene is about to be expressed. Non-coding RNAs (ncRNAs) are critical epigenetic components of plants because they regulate a variety of functions such as growth, development, and responses to environmental stresses. Non-coding RNAs are classified based on their length into two categories: short chain non-coding RNAs and long chain non-coding transcripts $[65,66]$. Short-chain non-coding RNAs, such as microRNAs (miRNAs) and small interfering RNAs (siRNAs), regulate gene expression at both the transcriptional and post-transcriptional levels, according to substantial literature conducted in animals and plants over the last few decades [67]. Both these are small RNAs with an average length of 18-24 nucleotides (nt) (sRNA) [68]. Long non-coding RNAs (lncRNAs) are non-coding RNAs with lengths greater than 200 nucleotides (nt) and are found in a wide variety of species [69]. RNA interference (RNAi) is a technique for post-transcriptional gene silencing that makes use of double-stranded RNA to silence genes following transcription [70]. It's a popular choice for gene function analysis because of the assay's high specificity and efficiency. Whereas, small interfering RNAs (siRNAs) can travel through plants using different carrier proteins (non-cell-autonomous travel), whereas miRNAs travel lesser distances.

\section{Tolerance to abiotic and biotic Stresses in members of Family Poaceae: The role of Epigenetic Machinery}

Abiotic and biotic stresses such as salinity, drought, heat, cold, submergence, heavy metal toxicity, weed/insect infestations and pathogen infections seriously threaten the growth and yield of important cereal crops such as rice, wheat, maize and barley [71]. Numerous research findings have led to new crop breeding programs for enhancing their resistance to such stresses. Recent years have seen an increase in evidence that plants use complex epigenetic processes to fine-tune their response to environmental stressors, which is consistent with known studies [72]. Here as necessary consequence, epigenetics has become one of the most popular research topics in plant functional genomics, as it appears to be particularly promising in terms of knowing plant species ability to adapt to environmental stress. Understanding the persistent and heritable characteristics of epigenetic marks and epigenetic regulatory systems has now become incredibly valuable for breeding capabilities. [73]. 
There's a growing body of evidence that methylation of DNA in response to stress causes phenotypic variation. This process has been linked to transposon mobility, siRNA-mediated methylation, and host methyl transferase activation. For example, the overall level of DNA methylation in a plant at the same developmental stage is lower in roots than in leaves, implying that both roots and leaves play a role in the plant's response to drought stress [74]. Drought, heat, and heavy metal toxicity all contribute to an increase in demethylation. Further, epigenetic mechanisms also play an active role in response of plants to biotic stresses, such as diseases caused by bacteria, viruses, fungi, parasites as well as insect and weed infestations, by controlling the expression of several resistance genes [28]. This immune memory state of plants is mediated by DNA methylation, RNA interference mechanisms, and histone modifications, and it is passed down to the next generation in few cases. Therefore, identifying of different mechanisms and studying their differential expressions in various tissues play a major role in research related to epigenetics [75]. Epigenetic mechanisms allow for alternative phenotypes with the same genetic sequence, which has resulted in a paradigm shift in genetics and ramifications across a wide range of disciplines. As a result, much effort has gone into deciphering epigenetic mechanisms, biological roles, and natural variation. Acquired knowledge about epigenetic responses in model plants can be transferred to cereal crops and used to increase phenotypic variation for breeding purposes due to recent advances in genome sequencing, bioinformatics tools, and associated techniques ChIPseq, FAIRE-seq, Chromosome Conformation Capture, or small RNA analysis.

\subsection{Epigenetic modifications for adaptation to abiotic stress tolerance}

Since the Green Revolution (1960s), rice (Oryza sativa L.) has been the world's most significant food crop, supplying staple food for almost half of the world's population and accounting for around $51 \%$ of human calorie consumption [76]. A 50\% reduction in biomass, 39\% reduction in grain yield and $28 \%$ reduction in straw yield of rice has been attributed to abiotic stresses [77] In terms of area and global food supply, wheat (Triticum aestivum L.) outperforms all other cereals [76]. It is farmed in a broad array of geographic regions across the globe, requiring the adaptation of its physiological responses to abiotic and biotic challenges [78]. It provides substantially more protein per gram (12-15\%) than rice or maize (2-3\%), making it a superior grain [79], but despite this, its output is much lower than those of rice and corn[80]. Extreme abiotic stresses such as drought, high temperature, and salinity, among others, will reduce wheat output by $20 \%-30 \%$, especially in developing countries [81]. Wheat yields are negatively impacted by stress throughout the reproductive stage of the plant [82]. Dubbed the queen of grains, maize (Zea mays L.) is cultivated in over 166 nations for various uses. Abiotic stresses such as moisture, high/low temperature, salt, and nutrition stress, in maize, have resulted in $17-60 \%$ of yield losses in various countries [83]. Although the crop possesses inherent resistance to severe conditions, abiotic stresses hamper its performance, corresponding to about $10-15 \%$ yield losses [84].

Wang et al. were the first to establish a link between abiotic stress responses and stress-induced epigenetic variation in rice by demonstrating that drought-tolerant and drought-susceptible rice cultivars displayed genotype- and tissue-specific differential DNA methylation upon imposing drought stress during the tillering stage [85]. Recent research employing the '-omics' technology has demonstrated a relationship between changed DNA methylation patterns and varied gene expression throughout the genome of three rice cultivars with variable susceptibilities to increasing salt and drought stress [86]. It has also been revealed that many HAT genes actively express in rice under heat and water stress. Elevated expression of HvTX1 in barley under drought stress suggests 
that it plays an active role in drought tolerance. Few other examples of epigenetic regulation for various abiotic stresses in different cereals are mentioned in Table 1.

\subsubsection{Salt-induced stress}

Salt accumulation in soil reduces the absorption of water and nutrients, leading to osmotic stress, ion toxicity, nutrient imbalance, and even water deficit [87;88]. DNA methylation alterations in salt-sensitive and salt-tolerant rice genotypes were observed in response to increasing salinity [85]. DNA methylation of retrotransposons, stress-responsive genes, and chromatin modification genes was found on several rice chromosomes [89]. The cytosine methylation and gene expression differences at these selected Methylation Sensitive Amplification Polymorphic (MSAP) sites were found independent of the salt tolerance of the rice genotype. Methylation of the gene body may be crucial for organ- and genotype-specific regulation of gene expression under salt stress. Ferreira et al. investigated a sequence of differentially methylated regions (DMRs) between control and salt-exposed plants [90], and a general trend towards demethylation was detected, similar to some earlier studies $(85,91)$. Overexpression of miR156 was reported to boost rice tolerance to salt stress while decreasing the expression of transcription factor target genes, which are primarily involved in forms of development [92]. These studies identified novel epigenetic mechanisms and target genes associated with rice genotypes' responses to salt stress, as well as new avenues for improving the crop's salt stress resistance.

Salt stress-induced reactions have activated few genes that are associated with the cell wall in maize roots, such as expansin 2 (ZmEXPB2) and xyloglucan endo trans glucosylase (ZmXET1). The upregulation of these genes' transcription has been linked to increased H3K9ac in their promoters and open reading frames. Subsequent research established that two HAT genes (ZmHATB and ZmGCN5) are responsible for the active acetylation of salt-responsive genes in maize [93]. In wheat, Singh et al. demonstrated that the root tissues of salt-tolerant (Kharchia-65) genotype were 30-40\% more methylated compared to shoot tissues. Due to the fact that roots are the first to encounter salt stress, they must limit access of $\mathrm{Na}^{+}$into root cells; thus, increased methylation in the root tissues of the salttolerant genotype (Kharchia-65) helped reduce $\mathrm{Na}^{+}$absorption from the soil. This suggested that the genes implicated in salt tolerance may be epigenetically controlled, with hypermethylation possibly inhibiting their expression, especially the high-affinity potassium transporters (HKTs). Additionally, they identified differences in HKT gene expression between salt-tolerant and salt-sensitive bread wheat genotypes in root and shoot tissues [94]. Also, distinct epigenetic alterations in particular genes such as HKTs in shoots and roots of wheat genotypes possessing variable degrees of vulnerability to salt stress was observed [95].

\subsubsection{Drought-induced stress}

Wang et al. elucidated that of the overall alterations in genome-wide DNA methylation in rice, around $12 \%$ accounted for drought-induced site-specific methylation across genotypes, tissues and developmental stages; of these, roughly $70 \%$ were reversed upon recovery while $29 \%$ remained preserved. Furthermore, drought tended to elicit DNA demethylation processes in the two cultivars studied, which were more severe during the tillering stage and varied across tissues and stages of physical growth [78]. When drought was applied at the panicle initiation stage in rice, hypomethylation was more evident in a drought-tolerant genotype than in a drought-susceptible genotype, according to another study using Methyl-Sensitive Amplification Polymorphism (MSAP) 
[96]. Since the past few years, much effort has been directed towards understanding the role of miRNAs in imparting tolerance to abiotic stresses in rice [97-103]. MiR159 was thought to function as a cellular regulator, guiding developmental or stress responses to external adverse situations [104]. Silencing the RINGfinger E3 ligase gene in rice, OsDSG1, improved drought tolerance [105] Zhang et al. silenced the miR166 that boosted drought tolerance in transgenic rice lines, and was accompanied by morphological alterations associated with the plants' natural stress responses [106]. It has been discovered that a significant proportion of drought-induced epi-mutations (DNA methylation) in rice retained their altered methylation pattern across successive generations when exposed to drought, from tillering to the grain filling, implying drought-induced epi-marks being heritable [107]. Santos et al. [108] demonstrated that rice's epigenetic processes and transcription factor activity cooperate to regulate abiotic stress responses.

Transcriptomic and genome-wide chromatin data were merged to determine how maize adjusts its response to and recovery from drought stress [109]. This work confirmed the presence of various chromatin-mediated levels of transcriptional regulation in response to osmotic stress $[110,111]$ as well as the dynamics of histone modifications related to H3K4me3 and H3K9ac [109]. Long non-coding RNA collections, encoding for drought stress-responsive maize transcripts expressed in a range of tissues, were uncovered in a genome-wide screen [112]. These LncRNAs were classified as sRNA precursors or other non-coding RNAs after being aligned with other sRNA databases. Xu et al. [113] discovered that natural antisense transcripts (NATs), were also present in two recombinant inbred lines, generated from these two parental lines and fixed for combination of drought tolerance loci that conferred high or low tolerance. While the function of NATs is unclear in plants, they also discovered that NATs related to stress reactions were considerably hypomethylated and included less transposons than non-NAT genes. Using genome-wide association study in maize, Mao et al. discovered that a miniature inverted repeat transposable element (MITE) that affect gene expression via RNA-directed DNA methylation (RdDM) and accumulation of $\mathrm{H} 3 \mathrm{~K} 9 \mathrm{me} 2$, resulting in drought tolerance [114].

Appels et al. investigated the whole wheat genome expression pattern utilizing 850 RNAseq samples from 32 tissues collected at different developmental stages by subjecting them to different stress treatments and found that poorly expressed genes on an average had a higher methylation status. Also, the distribution of the restrictive histone mark H3K27me3 (trimethylated histone H3 lysine 27) and the active histone mark H3K36me3 and H3K9ac (acetylated H3K9) were associated with the expression range patterns [115]. Gardiner et al. found that methylation patterns in wheat [116] in response to drought are not uniform throughout the A, B, and D subgenomes [117,118].

Terminal drought stress during grain filling is a primary abiotic factor limiting crop output in barley. In barley, the cytokinin-oxidase 2.1 (HvCKX 2.1) gene was noticed in their promoter regions of caryopsis when exposed to terminal drought, which is a stress-specific heterochromatic siRNA (hc-siRNA) of 24 mer length [119]. Interestingly, seeds generated from drought-stressed mother plants showed a faster rate of shoot emergence, perhaps owing to an overabundance of cytokinin ribosides. When exposed to drought, multiple differentially methylated sites are activated in leaves of the barley plant rather than in roots $[120,121]$. It was also observed that barley exhibited a more significant amount of DNA methylation than other crops such as rice and maize, maybe because the barley genome has a large percentage of duplicated sequences [122]. Droughtstressed barley plants had more compact nucleosome packing, and HSP17 was identified as a drought-responsive gene [123]. 


\subsubsection{Cold-induced stress}

Plant metabolism and the transcriptome are affected by cold stress, with key metabolic enzymes directly inhibited and gene expression reprogrammed [124]. Yang et al. observed overexpressed two miRNAs from the miR319 family, OSA-mir319a and OSA-mir319b, resulting in morphological changes [125]. Research revealed that increased acetylation of $\mathrm{H} 3 \mathrm{~K} 9$ in the upstream promoter regions of a rice gene OsDREB1 was related to cold-stress resistance through means of ChIP analysis [126]. Under cold temperatures, significant alterations in the expression of miR319 were detected in rice and sugarcane [127]. Hu et al. [128] observed that pretreatment of maize with the histone deacetylase (HDAC) inhibitor trichostatin A strongly reduces the induction of cold-stress responsive genes ZmDREB1 and ZmCOR413 in maize. These results demonstrated that HDACs activate the ZmDREB1 gene in response to cold exposure through histone modifications and chromatin structural changes and that this activation was both gene and location-specific $[128,129]$. A further comprehensive examination of individual genomic repeats demonstrated that cold stress selectively and transiently un-silenced tandem repetitive regions, resulting in an increase in $\mathrm{H} 3 \mathrm{~K} 9 \mathrm{ac}$ andreduced DNA methylationd $\mathrm{H} 3 \mathrm{~K} 9 \mathrm{me}$ 2.The tandem repeat genomic areas also underwent nucleosome remodelling [130]. Numerous transposable elements have also been reported that contribute towards the adaptability of a plant to environmental stress and a retro transposon-like motif that stays demethylated under cold stress [131]. While cold stress enhanced genome-wide DNA methylation in maize root tissues, genome sequencing showed that this $1.8 \mathrm{~kb}$ section, identified as ZmMI1, was demethylated after chilling treatment. Under normal circumstances, the same tract had a methylation percentage of roughly $38 \%$, double that of other locations. This gene segment encodes a fragment of a hypothetical protein-coding gene, hinting that it is involved in chilling tolerance [129].

\subsubsection{Heat-induced stress}

Plants exposed to high temperature (heat stress, HS), significant abiotic stress due to increased global warming, suffer from severe, and sometimes lethal, adverse effects. Plants have evolved complex mechanisms to respond to this kind of stress in order to cope with such conditions [132]. Another study on rice and heat stress found that OsFIE1 facilitated seed size reduction (fertilization-independent endosperm). DNA methylation and H3K9me2 methylation were shown to be two variables that influence OsFIE1 expression. Further investigation found that both DNA and histone methylation reduced under heat stress situations (DNA methylation dropped by 8.8 and 6.6 percent, respectively, in the $\mathrm{CH}$ and $\mathrm{CHG}$ contexts) [133]. Histone acetyltransferases (HATs) carried out acetylation of OsHAG702, OsHAG704, OsHAC701 and OsHAC704 loci in turn promoted heat stress tolerance in rice [134]. The modification of histone $\mathrm{H} 3$ lysine 4 (H3K4) me1/2 in wheat up-regulated the gene encoding the lysine-specific histone demethylase 1 (LSD1), which was involved in histone demethylation and promoted heat stress tolerance [135]. Ni et al. [136] found that the histone acetyltransferase TaGCN5 gene in wheat is up regulated under heat stress and that it functions similarly to GCN5 in Arabidopsis and noticed theH3K9 and H3K14 acetylation levels in the promoters of TaHSF1, TaHSF4, TaMBF1c, TaHSP17.4, and TaHSP101 that were significantly increased[137].

It was also observed that few miRNA families were also involved in heat stress response. Among them miR156, miR167, miR168 and miR398 were downregulated in rice [138], both up and down regulation was seen in miR160 [137], upregulation of miR167, miR156 and miR398 was studied in wheat [139] and in barley upregulation of miR160 and miR167 was identified [140]. Heat stress 
slows the development of maize and drastically affects crop production. By raising histone acetylation and reducing $\mathrm{H} 3 \mathrm{~K} 9 \mathrm{me} 3$ levels, heat stress has been demonstrated to trigger programmed cell death and modify chromatin structure [141]. Additionally, short-term heat stress generates dynamic H3K4me2 and $\mathrm{H} 3 \mathrm{~K} 9 \mathrm{ac}$ modifications in the promoter regions of maize seedlings, which are related with enhanced heat stress factor (Hsf) and rRNA gene expression, as well as membrane disturbances and an increase in reactive oxygen species [142]. It is observed that Histone deacetylases (HDAC gene) were downregulated under heat stress, and immune blotting results demonstrated that histones H3K9ac and H4K5ac levels were increased under heat stress in maize [143].

\subsubsection{Submergence-induced stress}

On the one hand, the world is currently facing difficulty as a consequence of global temperature increase, which has resulted in severe drought; on the other hand, the unexpected and regular occurrence of floods has become devastating across the world. Submergence induces a cocktail of stressors on the plant, including nutritional deprivation, hypoxia, infection, and low light, all of which are averse to the plant's output and life. Increased expression of two rice submergence-induced genes - alcohol dehydrogenase 1 (ADH1) and pyruvate decarboxylase 1 (PDC1) - was shown to be connected with reversible histone modifications, $\mathrm{H} 3$ acetylation and $\mathrm{H} 3 \mathrm{~K} 4$ trimethylation, respectively, from H3K4 dimethylation [144].

\subsubsection{Heavy metal-induced stress}

Concentrations of heavy metals over a particular level may have cytotoxic, genotoxic, and mutagenic effects on plants, resulting in abiotic stress situations [145]. Cadmium (Cd) could hinder antioxidant enzyme activity, impede regular cell division, and lessen photosynthesis in soils at low concentrations (0.3-0.8 mg kg -1) [146, 147]. Lead (Pb) accumulation is likely driven by Cd pollution in all major wheat-growing areas, posing a serious threat to crop yields and wellbeing [68]. Aluminium (Al) ions disrupt root development by reducing water and nutrient absorption in acid soils, resulting in lower crop yields [148]. DNA methylation is a critical epigenetic process in wheat and barley that regulates the plants' responses to environmental stresses such as salt and heavy metals [149, 150]. Wheat varieties than in heavy metal-sensitive varieties exposure to the heavy metal stresses. Suggesting that DNA methylation is associated with metal stress tolerance in wheat [150]. Meanwhile, low-level expression of HvAACT1 was found associated with a higher degree of DNA methylation in Multi Retrotransposon like MRL segments, suggesting that DNA methylation controls the expression of HvAACT1, the gene responsible for Aluminium stress tolerance in barley [151]. In the case of rice, the researchers discovered specific differentially methylated regions after $\mathrm{Cd}$ treatment, along with methylation patterns, and discovered that most epigenetically regulated genes were transcriptionally activated under Cd stress [152]. According to a report, heavy-metal stress caused locus-specific hypomethylation in treated rice seedling plants in somatic cells [153]. Ertuk et al. [154] identified excessive accumulation of zinc that reduced the activity of methyltransferases and caused hypomethylation of certain specific gene regions. Shafiq et al. [155] proposed that heavy metals alter the DNA methylation and histone acetylation levels through the activity of DNA methyltransferases and histone deacetylases mainly at ZIP transporters in the case of maize. Therefore in view of this prospect epigenetic modifications could be regarded as a valuable means for abiotic stress tolerance imposition. 
Table 1. Examples of abiotic Stress tolerance through epigenetic regulation crop plants of family Poaceae.

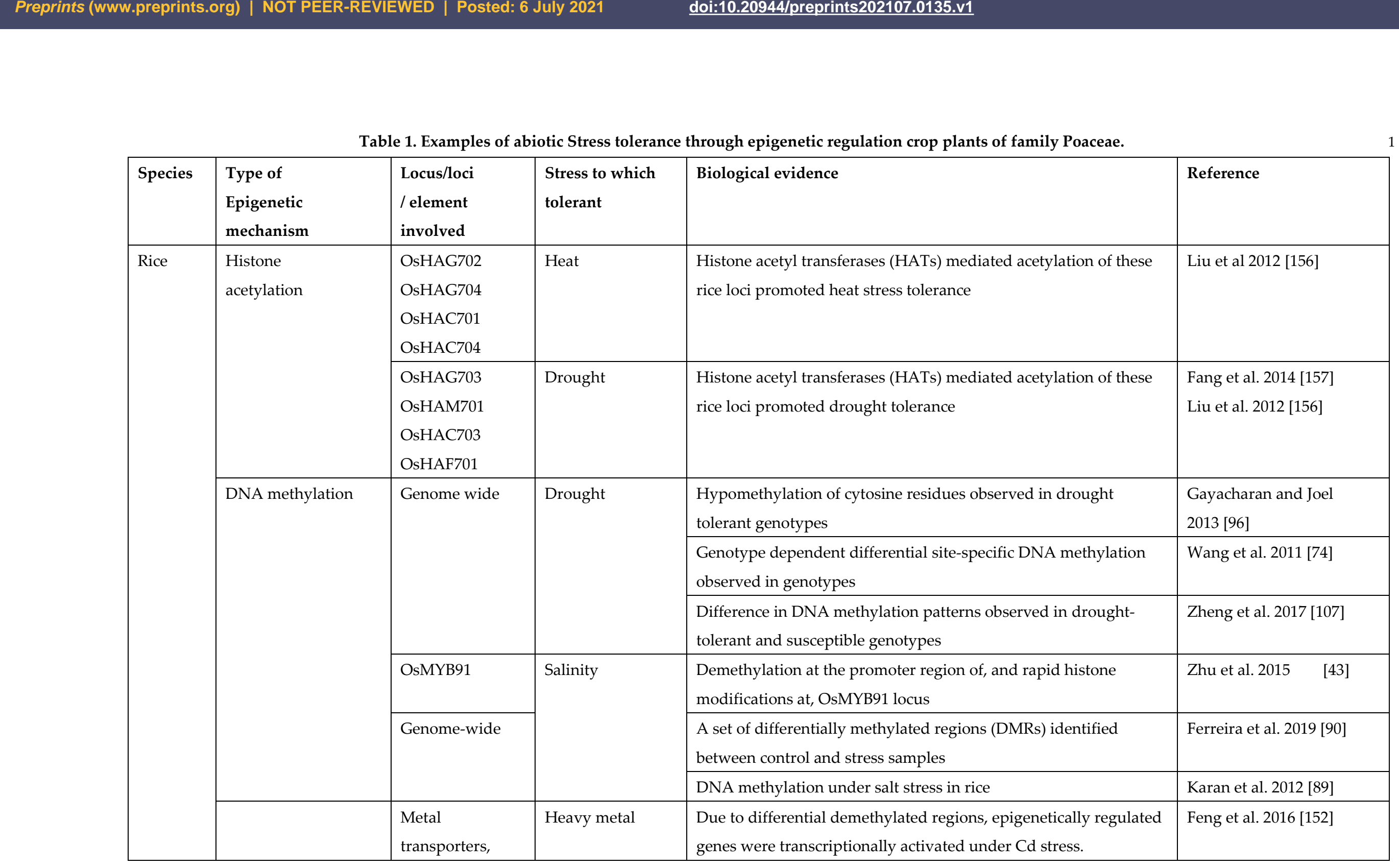




\begin{tabular}{|c|c|c|c|c|c|}
\hline & & $\begin{array}{l}\text { transcription } \\
\text { factors }\end{array}$ & & & \\
\hline & \multirow[t]{3}{*}{ RNAinterference } & $\begin{array}{l}\operatorname{miR} 170 \\
\operatorname{miR} 171 \\
\operatorname{miR} 172\end{array}$ & \multirow[t]{2}{*}{ Drought } & $\begin{array}{l}\text { Down regulation of miR170 expression } \\
\text { Up and down regulation of miR171 expression } \\
\text { Down regulation of miR172expression }\end{array}$ & Zhou et al 2010 [158] \\
\hline & & miR408 & & Up-regulation of miR408 expression & Muttum et al. 2013 [159] \\
\hline & & miR319 & Cold & Over expression of OsPCF5/PCF8 loci due to miR319 & Yang et al. 2013 [125] \\
\hline \multirow[t]{6}{*}{ Barley } & \multirow[t]{4}{*}{ DNA methylation } & HvDME & \multirow[t]{3}{*}{ Drought } & $\begin{array}{l}\text { Expression of HvDME was induced by drought stress, which was } \\
\text { correlated with differential DNA methylation patterns within the } \\
\text { gene }\end{array}$ & Kapazoglou et al. 2013 [41] \\
\hline & & HvTX1 & & $\begin{array}{l}\text { Expression of HvTXI was induced during seed development } \\
\text { under drought stress }\end{array}$ & $\begin{array}{l}\text { Papaefthimiou and } \\
\text { Tsaftaris } 2012[160]\end{array}$ \\
\hline & & HvCKX2.1 & & $\begin{array}{l}\text { Hyper-methylation of CYTOKNIN-OXIDASE promoter } 2.1 \text { by Hv- } \\
\text { siRNA }\end{array}$ & Surdonja et al. 2017 [119] \\
\hline & & HvAACT1 & Heavy metal & $\begin{array}{l}\text { Decreased expression of HvAACT1 was found associated with a } \\
\text { higher degree of DNA methylation in Multi Retrotransposon like } \\
\text { MRL segments responsible for Al stress tolerance }\end{array}$ & Kashino et al. 2018 [151] \\
\hline & $\begin{array}{l}\text { Histone } \\
\text { modification }\end{array}$ & $\begin{array}{l}\text { H3K4me3H3K9a } \\
\text { с H3K9me2 } \\
\text { H3 }\end{array}$ & \multirow[t]{2}{*}{ Drought } & $\begin{array}{l}\text { Increase in } \mathrm{H} 3 \mathrm{~K} 4 \mathrm{me} 3, \mathrm{H} 3 \mathrm{~K} 9 \mathrm{ac}, \mathrm{H} 3 \text { and loss in } \mathrm{H} 3 \mathrm{~K} 9 \mathrm{me} 2 \text { activity } \\
\text { was observed }\end{array}$ & Temel et al. 2017 [123] \\
\hline & RNA interference & miR408 & & Accumulation of miR408 transcripts was observed & Kantar et al. 2010 [161] \\
\hline \multirow[t]{2}{*}{ Wheat } & $\begin{array}{l}\text { Histone } \\
\text { acetylation }\end{array}$ & $\begin{array}{l}\text { TaGCN5 H3K9 } \\
\text { and H3K14 }\end{array}$ & Heat & $\begin{array}{l}\text { Under heat stress, the TaGCN5 gene in wheat is upregulated, and } \\
\text { acetylation levels of H3K9 and H3K14 in the promoters of } \\
\text { TaHSF1, TaHSF4, TaMBF1c, TaHSP17.4, and TaHSP101 were } \\
\text { significantly increased. }\end{array}$ & Ni et al. 2018 [136] \\
\hline & $\begin{array}{l}\text { Histone } \\
\text { demethylation }\end{array}$ & H3K4me1/2 & Heat & $\begin{array}{l}\text { Gene encoding lysine-specific histone demethylase } 1 \text {, involved in } \\
\text { histone demethylation, was up-regulated }\end{array}$ & Wang et al. 2016 [162] \\
\hline
\end{tabular}

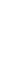




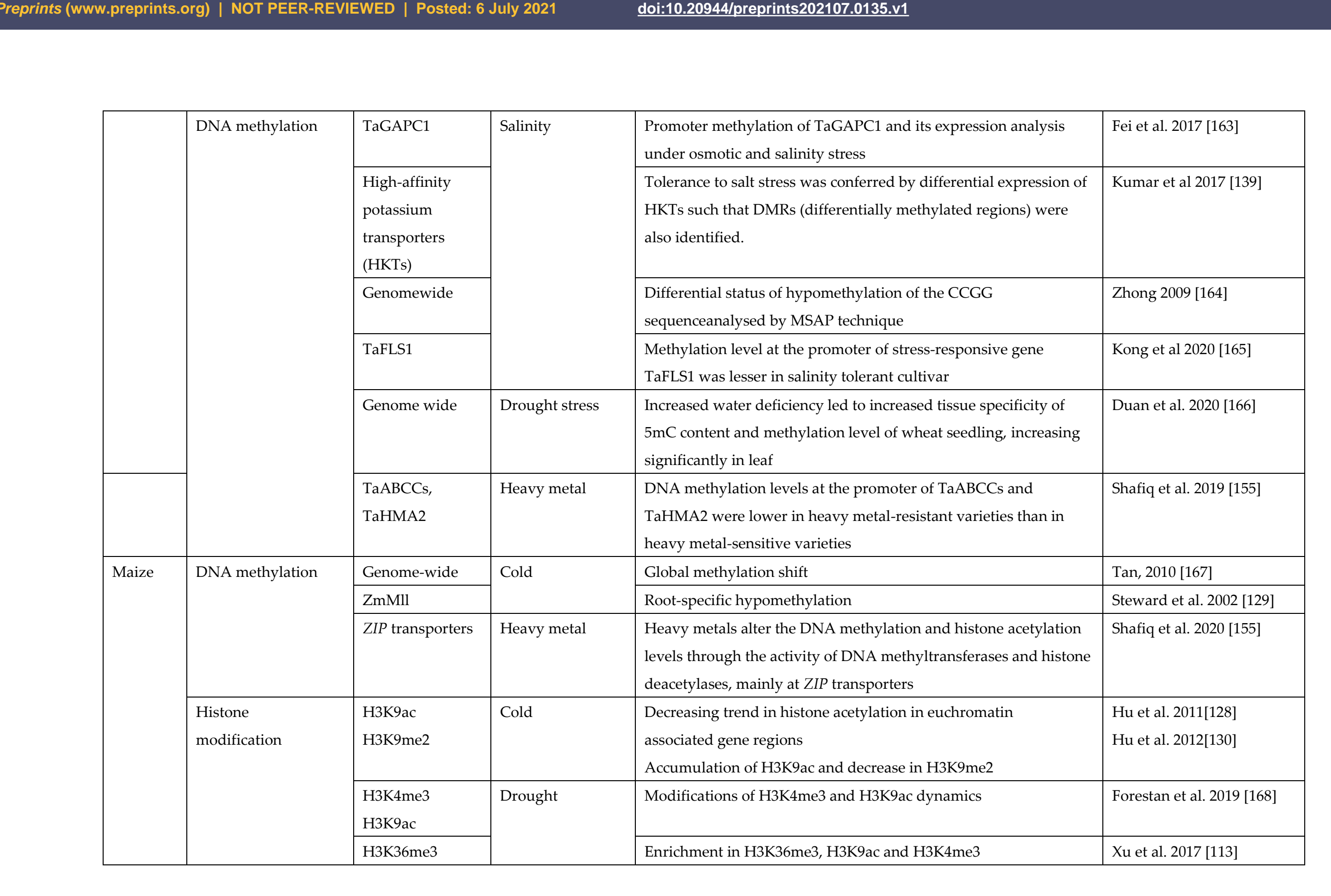




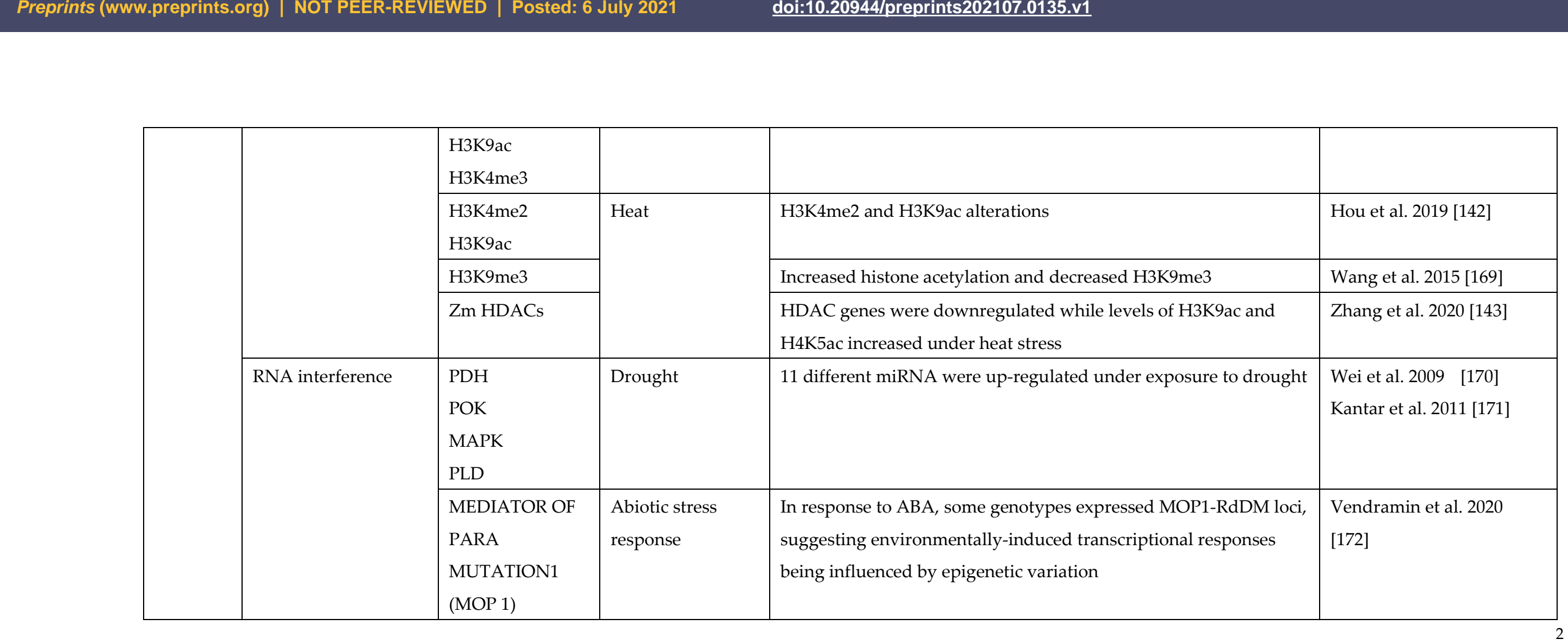




\subsection{Epigenetic modifications for adaptation to biotic stress tolerance}

Compared to abiotic stresses, there are fewer reports on epigenetic modifications for adaptation to biotic stresses. Few of these examples are enumerated in Table 2. In rice, one such example is the association of monoubiquitinated $\mathrm{H} 2 \mathrm{~A}$ and $\mathrm{H} 2 \mathrm{~B}$ histones with promoter regions targeted by the gene BRHIS1 (encoding SNF2 ATPase), which results in the suppression of immunity against the fungal pathogen that causes blast [173]. Rice has inheritable DNA methylation changes in response to salt and nitrogen deficiency stress. Notably, demethylation of the Xa21G promoter region was induced artificially to confer resistance to Xanthomonas oryzae pv. Oryzae overcomes the constitutive silence of the gene, which is caused by hypermethylation, resulting in the host developing resistance to infection. [174]. Deng et al. discovered that the rice Pigm locus contains a cluster of genes encoding nucleotide-binding leucine-rich repeat (NLR) receptors that impart long-lasting resistance to the fungus Magnaporthe Oryzae without jeopardising yield. This study elucidates a mechanism for balancing disease resistance and yield via epigenetic regulation of paired antagonistic NLR receptors, thereby paving the way for the development of elite crop varieties [175]. According to Li et al. DNA methylation of the promoter region of $P i b$ gene plays a significant role in configuring high levels of its induced expression during Magnaporthe grisea infection [176] and JMJ705, a biotic stress-responsive H3K27me2/3 demethylase [177].

JMJ704 enhances rice resistance to XanthomonasOryzaepv. Oryzae infection by lowering $\mathrm{H} 3 \mathrm{~K} 4 \mathrm{me} 2 / 3$, associated with negative disease resistance regulators [178]. A research by Demetriou et al. identified that the HD2 genes in barley have been linked to plant resistance to biotic stress conditions by enhancing $\mathrm{Ab}$ scisic acid (ABA), Salicylic acid (SA), and Jasmonic acid (JA) levels, implying that they are involved in stress resistance. HD2 genes' expression pattern suggests they could play a role in epigenetic control of seed development and stress response, according to the information $[179,180]$. Few reports showed that fungal pathogens account for $15 \%$ to $20 \%$ of annual yield losses in wheat $[181,182]$. Differences in the expression of genes encoding methyltransferases, non-coding RNAs, and histone acetylases/methyltransferases mediated by Lr28 related to Pucciniatriticinaleaf rust resistance.were discovered in previous transcriptome results [183]. With the development of high-throughput sequencing technology and computational methods, the research of ncRNA has been carried out gradually in wheat and barley [184-186]. Non-coding RNAs (ncRNAs), such as microRNAs (miRNAs), target mimics (TM), and other long non-coding RNAs (lncRNAs), have been implicated in the response to spot blotch disease and should be investigated in the same way that yellow rust and other abiotic stressors have been in wheat $[187,188]$.

In wheat diploid progenitor Aegilopstauschii, DNA methylation, specifically $\mathrm{CHH}$ methylation, is involved in the regulation of defence responses to Bgt (Blumeria graminis f. sp. tritici), the causal agent of wheat powdery mildew, according to a recent study. Differentially methylated regions (DMRs) were found to be associated with hypomethylation of $\mathrm{CHH}$ after Bgt infection [189]. qRfg1 is a causal gene in maize that is encoded by the ZmCCT gene, which is a CCT domain-containing gene that also contains a polymorphic CACTA-like transposable element (TE1) c. It is located 2.4 kilobases upstream of the ZmCCT gene, which is involved in human allelic variation. The non-TE1 ZmCCT allele appears to be poised, with both repressive (H3K27me3/H3K9me3) and active (H3K4me3) histone marks present in the anticipated bivalent chromatin of the non-TE1 ZmCCT allele. In this non-TE1 ZmCCT allele, there was a rapid but transient decrease in $\mathrm{H} 3 \mathrm{~K} 27 \mathrm{me} 3 / \mathrm{H} 3 \mathrm{~K} 9 \mathrm{me} 3$ and a progressive decrease in 
H3K4me3, resulting in disease resistance to Fusarium graminearum's Gibberella stalk rot, a maize-deadly disease [190]. Therefore, there was ample studies available on biotic stress tolerance through epigenetic means especially in poaceae family. 
Table 1. Examples of biotic Stress tolerance through epigenetic regulation crop plants of family Poaceae.

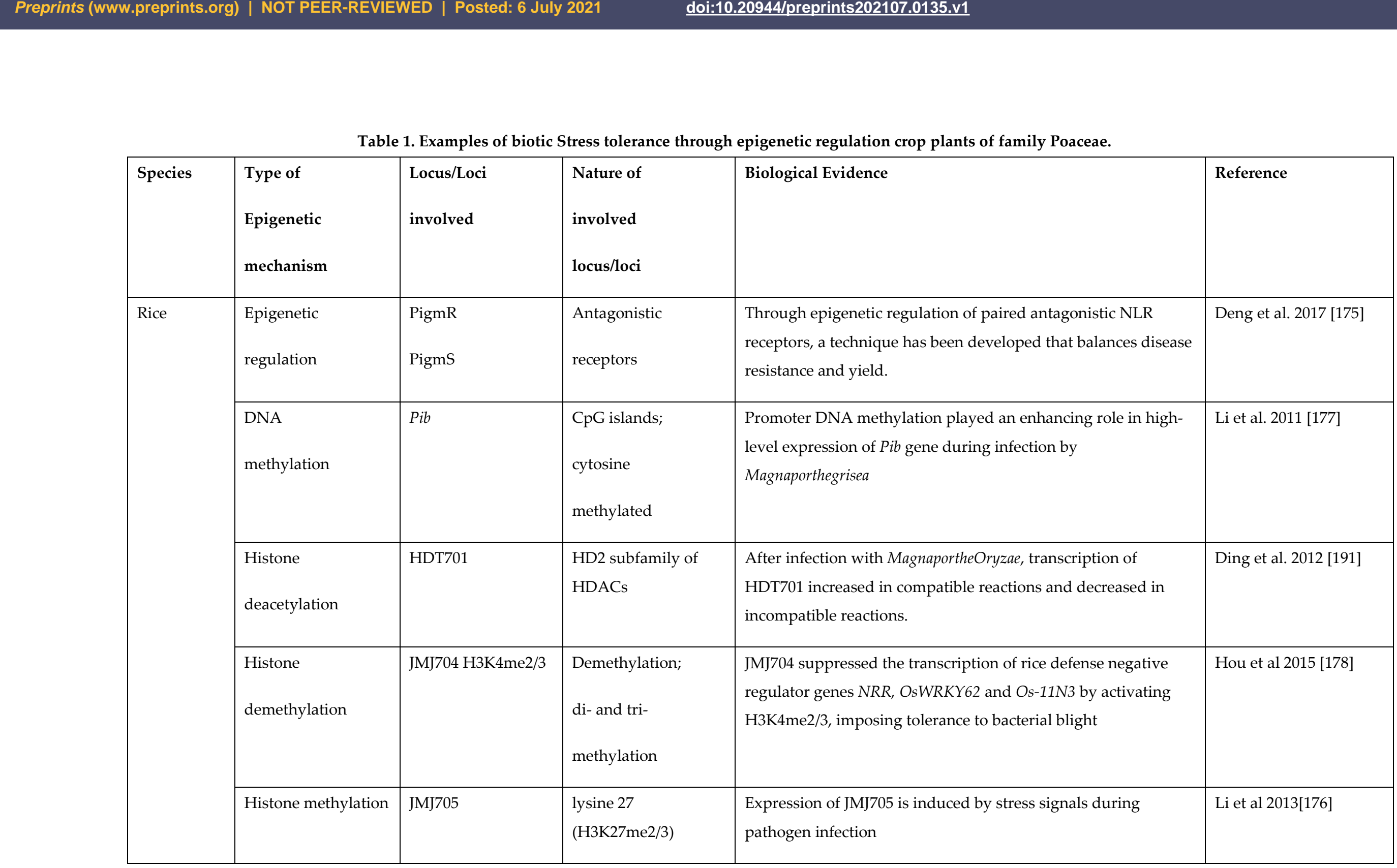




\section{Conclusion and Future Prospects}

As climate change is expected to increase the prevalence of extreme weather conditions, crops will become more vulnerable to various biotic and abiotic stresses. Therefore, enhanced stress tolerance becomes a significant breeding objective. Understanding of mechanisms that lead to one or more concurrently occurring stresses becomes important for their improvement. Evidence in favour of epigenetic mechanisms playing a role in increasing crop resilience to specific stresses is mounting by the day. An insight into the epigenetic mechanisms leading to stable, heritable phenotypic variation without changes in the underlying DNA sequence can potentially help plant breeders generate flexible varieties by exploiting such phenomena, providing an environment buffer under a rapidly changing climate. The recognition of epialleles and epigenetic regulatory systems with functional impacts on agronomic traits can lead to a range of epigenetic breeding strategies for crop plants, including the use of mutant lines, recurrent epi-selection, hybrid mimics, epigenomic selection and epigenome editing, along with exploitation of stress priming pathways to induce a constitutively primed state and increase the ability of the crop to tolerate stress without the undesired reduction in biomass accumulation and yield. Thus, epigenetics, together with functional genomics, has multiple implications in plant breeding. Traditional breeding methods for improving crop varieties are tedious, time-consuming, and expensive, and are unable to meet today's pragmatic demands. Epigenetics holds a great promise for improving plant varieties in terms of yield and nutritional quality through the creation of novel epialleles and through transgenic RNAi approaches.

Author Contributions: N.G., I.D. and P.K. conceived of and designed the project; P.K. supervised the study; V.P., R.K., N.G., M.S. and I.D. wrote the paper; P.K. checked and corrected the final draft. All authors have read and agreed to the published version of the manuscript.

Funding: This research received no external funding.

Institutional Review: Not applicable.

Informed Consent Statement: Not applicable.

Data Availability Statement: Not applicable.

Acknowledgments:

Conflicts of Interest: The authors declare no conflict of interest.

\section{References}

1. Awika, J. Major Cereal Grains Production and Use around the World. Adv. Cereal Sci. Implic. to Food Process. Heal. Promot. 2011, 1089, 1-13, doi:10.1021/bk-2011-1089.ch001.

2. Varotto, S.; Tani, E.; Abraham, E.; Krugman, T.; Kapazoglou, A.; Melzer, R.; Radanoviæ, A.; Miladinoviæ, D. Epigenetics: Possible applications in climate-smart crop breeding. J. Exp. Bot. 2020, 71, 5223-5236, doi:10.1093/jxb/eraa188.

3. Kumar, S. Epigenetics and Epigenomics for Crop Improvement : Current Opinion. Adv. Biotechnol. Microbiol. 2019, 14, 2025, doi:10.19080/AIBM.2019.14.555879.

4. S. Mahajan and N. Tuteja, "Cold, salinity and drought stresses: an overview," Archives of Biochemistry and Biophysics, vol. 444, no. 2, pp. 139-158, 2005.

5. Suzuki, N.; Rivero, R.M.; Shulaev, V.; Blumwald, E.; Mittler, R. Abiotic and biotic stress combinations. New Phytol. 2014, 203, 32-43. [CrossRef] [PubMed]

6. Nguyen, D.; D’ Agostino, N.; Tytgat, T.O.; Sun, P.; Lortzing, T.; Visser, E.J.; Cristescu, S.M.; Steppuhn, A.; Mariani, C.; van Dam, N.M. Drought and flooding have distinct effects on herbivore-induced responses and resistance in solanum dulcamara. Plant Cell Environ. 2016, 39, 1485-1499. [CrossRef] [PubMed]

7. Mirouze, M.; Paszkowski, J. Epigenetic contribution to stress adaptation in plants. Curr. Opin. Plant Biol. 2011, 14, 267-274, doi:10.1016/j.pbi.2011.03.004.

8. S. D. Horne, S. K. Chowdhury, and H. H. Q. Heng, "Stress, genomic adaptation, and the evolutionary trade-off," Frontiers in Genetics, vol. 5, article 92, 2014.

9. H. Peng and J. Zhang, "Plant genomic DNA methylation in response to stresses: potential applications and challenges in plant breeding," Progress in Natural Science, vol. 19, no. 9, pp. 1037-1045, 2009. 
10. Pecinka A, Chevalier C, Colas I, Kalantidis K, Varotto S, Krugman T, Michailidis C, Pilar Vallés M, Muñoz A, Pradillo M. 2020. Chromatin dynamics during interphase and cell division: similarities and differences between model and crop plants. Journal of Experimental Botany, 71, 5205-5222.

11. Nuruddin, M.M.; Madramootoo, C.A.; Dodds, G.T. Effects of water stress at different growth stages on greenhouse tomato yield and quality. HortScience 2003, 38, 1389-1393

12. Greven, M.M.; Raw, V.; West, B.A. Effects of timing of water stress on yield and berry size. Water Sci. Technol. 2009, 60, 1249-1255. [CrossRef] [PubMed]

13. Ottman, M.; Kimball, B.A.; White, J.; Wall, G.W. Wheat growth response to increased temperature from varied planting dates and supplemental infrared heating. Agron. J. 2012, 104, 7. [CrossRef]

14. Zhao, C.; Piao, S.; Wang, X.; Huang, Y.; Ciais, P.; Elliott, J.; Huang, M.; Janssens, I.A.; Li, T.; Lian, X.; et al. Plausible rice yield losses under future climate warming. Nat. Plants 2016, 3, 16202. [CrossRef] [PubMed]

15. Bassu, S.; Brisson, N.; Durand, J.-L.; Boote, K.; Lizaso, J.; Jones, J.W.; Rosenzweig, C.; Ruane, A.C.; Adam, M.; Baron, C.; et al. How do various maize crop models vary in their responses to climate change factors? Glob. Change Biol. 2014, 20, 2301-2320. [CrossRef] [PubMed]

16. Atkinson, N.J.; Urwin, P.E. The interaction of plant biotic and abiotic stresses: From genes to the field. J.f Exp. Bot. 2012, 63, 3523-3543. [CrossRef] [PubMed]

17. Tsaftaris, A.S.; Polidoros, A.N.; Kapazoglou, A.; Tani, E. Epigenetics and Plant Breeding. 2008, 30, 49-178.

18. Hu, Z.; Song, N.; Zheng, M.; Liu, X.; Liu, Z.; Xing, J.; Ma, J.; Guo, W.; Yao, Y.; Peng, H.; et al. Histoneacetyltransferase GCN5 is essential for heat stress-responsive gene activation and thermotolerance inArabidopsis. Plant J. 2015, 84, 11781191.

19. Colicchio, J.M.; Miura, F.; Kelly, J.K.; Ito, T.; Hileman, L.C. DNA methylation and gene expression in Mimulus guttatus. BMC Genomics 2015, 1-15, doi:10.1186/s12864-015-1668-0.

20. Chen, D.; Chen, D.; Xue, R.; Long, J.; Lin, X.; Lin, Y.; Jia, L.; Zeng, R.; Song, Y. Effects of boron, silicon and their interactions on cadmium accumulation and toxicity in rice plants. J. Hazard. Mater. 2019, 367, 447-455. [CrossRef]

21. Kim, S.; Ramos, J.M.; Hizon, R.J.M.; Ashikari, M.; Virk, P.S.; Torres, E.A.; Nissila, E.; Jena, K.K. Introgression of a functional epigenetic OsSPL 14 WFP allele into elite indica rice genomes greatly improved panicle traits and grain yield. Sci. Rep. 2018, 1-12, doi:10.1038/s41598-018-21355-4.

22. Kinoshita, T.; Seki, M. Epigenetic memory for stress response and adaptation in plants. Plant Cell Physiol. 2014, 55, 18591863, doi:10.1093/pcp/pcu125.

23. Eichten, S.R.; Schmitz, R.J.; Springer, N.M. Epigenetics: Beyond Chromatin Modifications and Complex Genetic Regulation. Plant Physiol. 2014, 165, 933-947.

24. Iwasaki, M.; Paszkowski, J. Epigenetic memory in plants. The EMBO Journal 2014, 33, 1987-1998.

25. Vriet, C.; Hennig, L.; Laloi, C. Stress-induced chromatin changes in plants: of memories, metabolites and crop improvement. Cell. Mol. Life Sci. 2015, 72, 1261-1273, doi:10.1007/s00018-014-1792-z.

26. Sudan, J.; Raina, M.; Singh, R. Plant epigenetic mechanisms: role in abiotic stress and their generational heritability. 3 Biotech. 2018, 8, 172, doi:10.1007/s13205-018-1202-6.

27. Friedrich, T.; Faivre, L.; Bäurle, I.; Schubert, D. Chromatin-based mechanisms of temperature memory in plants. Plant Cell Environ. 2019, 42, 762-770. [CrossRef]

28. Lämke, J.; Bäurle, I. Epigenetic and chromatin-based mechanisms in environmental stress adaptation and stress memory in plants. Genome Biol. 2017, 18, 124. [CrossRef]

29. Springer, N.M.; Schmitz, R.J. Exploiting induced and natural epigenetic variation for crop improvement. Nat. Rev. Genet. 2017, 18, 563-575. [CrossRef]

30. Mette, M.F.; Aufsatz, W.; Kanno, T.; Daxinger, L.; Rovina, P.; Matzke, M.; and Matzke, A.J.Analysis of double-stranded RNA and small RNAs involved in RNA-mediated transcriptional gene silencing. Methods Mol. Biol. 2005, 309: 61-82

31. Fuks, F. DNA methylation and histone modifications: teaming up to silence genes. Curr. Opin. Genet. Dev. 2005, 15, 490495, doi:10.1016/j.gde.2005.08.002.

32. Ramu, V.S.; Paramanantham, A.; Ramegowda, V.; Mohan-Raju, B.; Udayakumar, M.; Senthil-Kumar, M. Transcriptome analysis of sunflower genotypes with contrasting oxidative stress tolerance reveals individual and combined-biotic and abiotic stress tolerance mechanisms. PLoS One 2016, 11, e0157522.

33. Niederhuth, C.E.; Bewick, A.J.; Ji, L.; Alabady, M.S.; Kim, K.D.; Li, Q.; Rohr, N.A.; Rambani, A.; Burke, J.M.; Udall, J.A. et al. Widespread natural variation of DNA methylation within angiosperms. Genome Biol. 2016, 17, 194. [CrossRef]

34. Chin, SP.; Dickinson, JL.; and Holloway, AF. Epigenetic regulation of prostate cancer. Clin Epigenetics. $2011,2,151-169$. 
35. Majumdar, S.; Buckles, E.; Estrada, J.; Koochekpour, S. Aberrant DNA methylation and prostate cancer. Curr Genomics. 2011, 12, 486-505.

36. Deleris, A.; Halter, T.; Navarro, L. DNA methylation and demethylation in plant immunity. Annual Review of Phytopathology 2016, 54, $579-603$.

37. Zemach, A.; Kim, MY.; Hsieh, PH.; Coleman-Derr, D.; Eshed-Williams, L.; Thao, K.; Harmer, SL.; Zilberman, D. The Arabidopsis nucleosome remodeler DDM1 allows DNA methyltransferases to access H1-containing heterochromatin. Cell 2013, 153, 193-205.

38. Penterman, J.; Zilberman, D.; Huh, JH.; Ballinger, T.; Henikoff, S.; Fischer, RL. DNA demethylation in the Arabidopsis genome. Proceedings of the National Academy of Sciences, USA 2007, 104, 6752-6757.

39. Khan, A.; Zinta, G. Drought stress and chromatin: an epigenetic perspective. Drought Stress Tolerance in Plants 2016, 2, 571586

40. Choi, Y.; Gehring, M.; Johnson, L.; Hannon, M.; Harada, J.J.; Goldberg, R.B.; Jacobsen, S.E.; Fischer, R.L. DEMETER, a DNA glycosylase domain protein, is required for endosperm gene imprinting and seed viability in arabidopsis. Cell 2002, 110, 33-42, doi:10.1016/s0092-8674(02)00807-3.

41. Kapazoglou, A.; Drosou, V.; Argiriou, A.; Tsaftaris, A.S. The study of a barley epigenetic regulator, HvDME,in seed development and under drought. BMC Plant Biol. 2013, 13, 172

42. Lyko, F. Novel methods for analysis of genomic DNA methylation. Anal. Bioanal. Chem. 2005, 381, 67-68, doi:10.1007/s00216-004-2903-8.

43. Zhu, J.K. Active DNA demethylation mediated by DNA glycosylases. Annu. Rev. Genet. 2009, 43, 143-166. [CrossRef] [PubMed]

44. Gehring, M.; Reik, W.; Heniko, S. DNA demethylation by DNA repair. Trends Genet. 2009, 25, 82-90. [CrossRef] [PubMed]

45. Bannister, A.J.; Kouzarides, T. Regulation of chromatin by histone modifications. Nat. Publ. Gr. 2011, 381-395, doi:10.1038/cr.2011.22.

46. Lawrence. M.;Daujat, S.; Schneider, R. Lateral thinking: how histone modifications regulate gene expression. Trends Genet. 2016, 32, 42-56.

47. Kouzarides, T. Chromatin modifications and their function, Cell. 2007, 128

48. Ruthenburg, A.J.; Li, H.; Patel, D.J.; Allis, C.D. Multivalent engagement of chromatin modifications by linked binding modules, Nat Rev Mol Cell Biol. 2007, 8, 983-994.

49. Kanwal,R.;Gupta,S. Epigenetic modifications in cancer, Clin Genet. 2012, 81, 303-311.

50. Wei, W.; Tao, JJ.; Chen, HW.; Li, QT.; Zhang, WK.; Ma, B.; Lin, Q.; Zhang, JS.; Chen, SY. A histone code reader and a transcriptional activator interact to regulate genes for salt tolerance. Plant Physiology 2017, 175, 1304-1320.

51. Dhar, M.K.; Vishal, P.; Sharma, R.; Kaul, S. Epigenetic Dynamics: Role of Epimarks and Underlying Machinery in Plants Exposed to Abiotic Stress. 2014, doi:10.1155/2014/187146.

52. Turner, B.M. Cellular memory and the histone code. Cell 2002, 111, 285-291, doi:10.1016/s0092-8674(02)01080-2.

53. Liu, G.; Khan, N.; Ma, X.; Hou, X. Identification, Evolution, and Expression Profiling of Histone Lysine Methylation Moderators in Brassica rapa. Plants 2019, 8, 526. [CrossRef] [PubMed]

54. Jenuwein,T.; Allis, C.D. Translating the histone code, Science, 2001, 293, 1074-1080.

55. Vahid, F. H. Z.; Nosrat-Mirshekarlou, E.; Najafi, R.; Hekmatdoost, A. The role dietary of bioactive compounds on the regulation of histone acetylases and deacetylases: a review, Gene, 2015, 562, 8-15.

56. Martienssen, R. A.; Colot, V. DNA methylation and epigenetic inheritance in plants and filamentous fungi. Science 2001, 293, 1070-1074. doi: 10. 1126/science.293.5532.1070

57. Weake, V.M.; Workman, J.L. Histone ubiquitination: triggering gene activity, Mol Cell. 2008, 29, 653-663.

58. Jason, L.J.; Moore, S.C.; Lewis, J.D.; Lindsey, G.; Ausio, J. Histone ubiquitination: a tagging tail unfolds. Bioessays, 2002, 24, 166-174.

59. Shiio, Y.; Eisenman, R.N. Histone sumoylation is associated with transcriptional repression, Proc Natl Acad Sci U S A. 2003, 100, 13225-13230.

60. Annalisa, I.; Robert, S. The role of linker histone H1 modifications in the regulation of gene expression and chromatin dynamics. BiochimBiophys Acta, 2015.

61. Maleszewska, M.; Kaminska, B. Deregulation of histone-modifying enzymes and chromatin structure modifiers contributes to glioma development, Future Oncol. 2015, 11, 2587-2601.

62. Chen, W.; Zhu, Q.; Liu, Y.; Zhang, Q. Chromatin Remodeling and Plant Immunity. Adv. Protein Chem. Struct. Biol. 2017, 106, 243-260.

63. Guo, X.; Yang, D.; Zhang, X. Epigenetics recording varied environment and complex cell events represents the origin of cellular aging. J. Zhejiang Univ. B 2019, 20, 550-562, doi:10.1631/jzus.B1800507.

64. Fenley, A.T.; Anandakrishnan, R.; Kidane, Y.H.; Onufriev, A.V. Modulation of nucleosomal DNA accessibility via chargealtering post-translational modifications in histone core. Epigenet. Chromatin 2018, 11, 11. [CrossRef] 
65. Hou, J.; Lu, D.; Mason, A.S.; Li, B.; Xiao, M.; An, S.; Fu, D. Non-coding RNAs and transposable elements in plant genomes: Emergence, regulatory mechanisms and roles in plant development and stress responses. Planta 2019, 250, 23-40. [CrossRef]

66. Brant, E.J.; Budak, H. Plant small non-coding RNAs and their roles in biotic stresses. Front. Plant Sci. 2018, 9, 1038. [CrossRef]

67. Wang, J.; Meng, X.; Dobrovolskaya, O.B.; Orlov, Y.L.; Chen, M. Non-coding RNAs and their roles in stress response in plants. Genomics Proteomics Bioinform. 2017, 15, 301-312. [CrossRef]

68. Aprile, A.; Sabella, E.; Francia, E.; Milc, J.; Ronga, D.; Pecchioni, N.; Ferrari, E.; Luvisi, A.; Vergine, M.; De Bellis, L. Combined Effect of Cadmium and Lead on Durum Wheat. Int. J. Mol. Sci. 2019, 20, 5891. [CrossRef] [PubMed]

69. Mach, J. The long-noncoding RNA ELENA1 functions in plant immunity. Plant Cell 2017, 29, 916. [CrossRef]

70. Ravichandran, S.; Ragupathy, R.; Edwards, T.; Domaratzki, M.; Cloutier, S. MicroRNA-guided regulation of heat stress response in wheat. BMC Genomics 2019, 20, 488. [CrossRef]

71. Liu, J.; Feng, L.; Li, J.; He, Z. Genetic and epigenetic control of plant heat responses. Front. Plant Sci.2015, 6, 267, doi:10.3389/fpls.2015.00267.

72. Chang, Y.N.; Zhu, C.; Jiang, J.; Zhang, H.; Zhu, J.K.; Duan, C.G. Epigenetic regulation in plant abiotic stress responses. J. Integr. Plant Biol. 2020, 62, 563-580, doi:10.1111/jipb.12901.

73. Gallusci, P.; Dai, Z.;Genard, M.;Gauffretau, A.; Leblanc-Fournier, N.; Richard-Molard, C.; Vile. D.; Brunel-Muguet, S.Epigenetics for plant improvement: current knowledge and modeling avenues. Trends in Plant Science, 2017, 22, 610-623.

74. Wang, W.S.; Pan, Y.J.; Zhao, X.Q.; Dwivedi, D.; Zhu, L.H.; Ali, J.; Fu, B.Y.; Li, Z.K. Drought-induced site-specific DNA methylation and its association with drought tolerance in rice (Oryza sativa L.). J. Exp. Bot. 2011, 62, 1951-1960, doi:10.1093/jxb/erq391.

75. Sun, X.; Zhang, H.; Sui, N. Regulation mechanism of long non-coding RNA in plant response to stress. Biochem. Biophys. Res. Commun. 2018, 503, 402-407. [CrossRef]

76. FAO. 2018. FAOSTAT. Rome: Food and Agriculture Organization of the United Nations. http://www.fao.org/faostat/en/ (accessed on 28 June 2021).

77. Prince, SJ.; Beena, R.; Gomez, SM. et al. Mapping consistent rice (Oryza sativa L.) yield QTLs under drought stress in target rainfed environments. Rice. 2015, 8 (25):1-13

78. Avni, R.; Nave, M.; Barad, O.; Baruch, K.; Twardziok, S.O.; Gundlach, H.; Hale, I.; Mascher, M.; Spannagl, M.; Wiebe, K. et al. Wild emmer genome architecture and diversity elucidate wheat evolution and domestication. Science 2017, 357, 93-97, doi:10.1126/science.aan0032.

79. Tack, J. T.; Barkley, A.; Nalley, L. L. Effect of warming temperatures on US wheat yields. Proc. Natl. Acad. Sci. U.S.A. 2015, 112, 6931-6936. doi: 10.1073/pnas.1415181112

80. FAO (2017). FAOSTAT. Food Agriculture. Organization. United Nations. Available at: http://www.fao.org/faostat/en/\#home [accessed 28 June 2021].

81. Hossain, A.; Skalicky, M.; Brestic, M.; Maitra, S.; Ashraful Alam, M.; Syed, M.A.; Hossain, J.; Sarkar, S.; Saha, S.; Bhadra, P. et al. Consequences and Mitigation Strategies of Abiotic Stresses in Wheat (Triticum aestivum L.) under the Changing Climate. Agronomy 2021, 11, 241, doi:10.3390/agronomy11020241.

82. Begcy, K., \&Dresselhaus, T. Epigenetic responses to abiotic stresses during reproductive development in cereals. Plant Reproduction 2018, 31, 343-355

83. Yadav, S.; Modi, P.; Dave, A.; Vijapura, A.; Patel, D.; Mohini, P. Effect of Abiotic Stress on Crops 2019, intech books.

84. Rani, S.; Chaudhary, A.; Rani, K. Management of abiotic stress in barley (Hordeum vulgare L.). Wheat Barley Res.2019, 10, doi:10.25174/2249-4065/2018/85229.

85. Wang, K.C.; Chang, H.Y. Molecular Mechanisms of Long Noncoding RNAs. Mol. Cell. 2011, 43, 904-914, doi:https://doi.org/10.1016/j.molcel.2011.08.018.

86. Garg, R.; Narayana Chevala,V. V. S.; Shankar,R.; and Jain.M. Divergent DNA methylation patterns associated with gene expression in rice cultivars with contrasting drought and salinity stress response. Scientific Reports 2015, 5, 14922.

87. Zörb, C.; Geilfus, C.M.; Dietz, K.J. Salinity and crop yield. Plant Biol. 2019.

88. Hanin, M.; Ebel, C.; Ngom, M.; Laplaze, L.; Masmoudi, K. New insights on plant salt tolerance mechanisms and their potential use for breeding. Front. Plant Sci. 2016, 7, 1787. [CrossRef]

89. Karan, R.; DeLeon, T.; Biradar, H.; Subudhi, P.K. Salt stress induced variation in DNA methylation pattern and its influence on gene expression in contrasting rice genotypes. PLoS One 2012, 7, doi:10.1371/journal.pone.0040203.

90. Ferreira, L.J.; Donoghue, M.T.A.; Barros, P.; Saibo, N.J.; Santos, A.P.; Oliveira, M.M. Uncovering Differentially Methylated Regions (DMRs) in a Salt-Tolerant Rice Variety under Stress: One Step towards New Regulatory Regions for Enhanced Salt Tolerance. Epigenomes 2019, 3, 4, doi:10.3390/epigenomes3010004.

91. Ferreira, L.L.; Couto, R.; Oliveira, P.J. Bisphenol A as epigenetic modulator: setting the stage for carcinogenesis? Eur. J. Clin. Invest. 2015, 45, 32-36, doi: https://doi.org/10.1111/eci.12362.

92. Cui, L.G.; Shan, J.X.; Shi, M.; Gao, J.P.; Lin, H.X. The miR156-SPL9-DFR pathway coordinates the relationship between development and abiotic stress tolerance in plants. The Plant Journal 2014, 80, 1108-1117 
93. Li, L.; Eichten, S.R.; Shimizu, R.; Petsch, K.; Yeh, C.; Wu, W.; Chettoor, A.M.; Givan, S.A.; Cole, R.A.; Fowler, J.E. et al. Genome-wide discovery and characterization of maize long non-coding RNAs. 2014, 1-15.

94. Singh, A.; Bhushan, B.; Gaikwad, K.; Yadav, OP.; Kumar, S. et al. Induced defence responses of contrasting bread wheat genotypes under differential salt stress imposition. Ind J BiochemBiophys 2015, 52(1): 75-85.

95. Kumar, S.; Beena, A.S.;Awana, M.; and Singh, A. Salt-induced tissue-specific cytosine methylation downregulates expression of HKT genes in contrasting wheat (Triticum aestivum L.) genotypes. DNA and cell biology. 2017, 36(4): $283-294$.

96. Gayacharan, Joel, A.J. Epigenetic responses to drought stress in rice (Oryza sativa L.). Physiol. Mol. Biol. Plants 2013, 19, 379-387, doi:10.1007/s12298-013-0176-4.

97. Grewal, RK.; Saraf, S.; Deb, A.; Kundu, S. Differentially expressed microRNAs link cellular physiology to phenotypic changes in rice under stress conditions. Plant $\mathcal{E}$ Cell Physiology 2018, 59, 2143-2154.

98. Jeong, DH.; Green, PJ. The role of rice microRNAs in abiotic stress responses. Journal of Plant Biology. 2013, 56, 187-197

99. Shriram, V.; Kumar, V.;Devarumath, RM.;Khare, TS.;Wani, SH.MicroRNAs as potential targets for abiotic stress tolerance in plants. Frontiers in Plant Science 2016, 7, 817

100. Nadarajah, K.; Kumar, IS. Drought response in rice: The miRNA story. International Journal of Molecular Science 2019, 20, 3766.

101. Kumar, S.;Beena, AS.;Awana, M.; Singh, A.Physiological, biochem- ical, epigenetic and molecular analyses of wheat (Triticum aestivum $\mathrm{L}$ ) geno- types with contrasting salt tolerance. Frontiers in Plant Science 2017, 8, 115.

102. Patel, P.; Yadav, K.; Srivastava, Ak.;Suprasanna, P.; Ganapathi, TR. Overexpression of native Musa-miR397 enhances plant biomass without compromising abiotic stress tolerance in banana. Scientific Reports 2019, 9, 16434.

103. Xu, J.;Hou, QM.;Khare, T.;Verma, SK.; Kumar, V. Exploring miRNAs for developing climate-resilient crops: a perspective review. The Science of the Total Environment 2019, 653, 91-104.

104. Kumar, A.; Kaur, R.; Rajam, M.V. Regulatory Role of Micro-RNAs in Plants Under Challenging Environmental Conditions with Special Focus on Drought and Salinity. In Harsh Environment and Plant Resilience: Molecular and Functional Aspects; Husen, A., Ed.; Springer International Publishing: Cham, 2021, pp. 121-140 ISBN 978-3-030-65912-7.

105. Park, G. G.; Park, J. J.; Yoon, J.; Yu, S. N.; An, G. A RING finger E3 ligase gene, Oryza sativa delayed seed germination 1 (OsDSG1), controls seed germination and stress responses in rice. Plant Mol. Biol. 2014, 74:467-478. 10.1007/s11103-0109687-3 [PubMed] [CrossRef] [Google Scholar]

106. Zhang, J.; Zhang, H.; Srivastava, AK.; Pan, Y.; Bai, J.; Fang, J.; Shi, H.; Zhu, JK.; Knockdown of rice micro RNA166 confers drought resistance by causing leaf rolling and altering stem xylem development. Plant Physiol. 2018, 176, 2082-2094 PubMed CrossRef Google Scholar

107. Zheng, X.; Chen, L.; Xia, H.; Wei, H.; Lou, Q.; Li, M.; Li, T.; Luo, L. Transgenerational epimutations induced by multi-generation drought im- position mediate rice plant's adaptation to drought condition. Scientific Reports. 2017, 7, 39843.

108. Santos, A. P.; Serra, T.; Figueiredo, D. D.; Barros, P.; Lourenco, T.; Chander, S.; Oliveira, M. M.; Saibo, N. J. Transcription regulation of abiotic stress responses in rice: a combined action of transcription factors and epigenetic mechanisms. OMICS 2011, 15, 839-857

109. Forestan, C.; Farinati, S.; Rouster, J.; Lassagne, H.; Lauria, M.; Dal Ferro, N.; Varotto, S. Control of maize vegetative and reproductive development, fertility, and rRNAs silencing by HISTONE DEACETYLASE. Genetics 2018, 208, $1443-1466$.

110. Lunardon, A.; Forestan, C.; Farinati, S.; Axtell, M.J.; Varotto, S. Genome-wide characterization of maize small RNA loci and their regulation in the required to maintain repression 6-1 (rmr6-1) mutant and long-term abiotic stresses. Plant Physiology 2016, 170, 1535-1548.

111. Forestan, C.; Aiese,Cigliano, R.; Farinati, S.; Lunardon, A.; Sanseverino, W.; Varotto, S. Stress-induced and epigeneticmediated maize transcriptome regulation study by means of transcriptome reannotation and differential expression analysis. Scientific Reports 2016, 6, 30446.

112. Zhang, W.; Han, Z.; Guo, Q.; Liu, Y.; Zheng, Y.; Wu, F.; Jin, W.. Identification of maize long non-coding RNAs responsive to drought stress. PLoS One 2014, 9, e98958

113. Xu, J.; Wang, Q.; Freeling, M. et al. Natural antisense transcripts are significantly involved in regulation of drought stress in maize. Nucleic Acids Research 2017, 45, 5126-5141.

114. Mao, H.; Wang, H.; Liu, S.; Li, Z.; Yang, X.; Yan, J.; Li, J.; Tran, LS.; Qin, F. A transposable element in a NAC gene is associated with drought tolerance in maize seedlings. Nat Commun 2015, 6, 8326

115. Appels, R.; Eversole, K.; Stein, N. et al. Shifting the limits in wheat research and breeding using a fully annotated reference genome. Science 2018, 361, eaar7191.

116. Gardiner, L.J.; Quinton-Tulloch, M.; Olohan, L.; Price, J.; Hall, N.; Hall, A. A genome-wide survey of DNA methylation in hexaploid wheat. Genome Biology 16, 273

117. Budak H, Hussain B, Khan Z, Ozturk NZ, Ullah N. From genetics to functional genomics: improvement in drought signaling and tolerance in wheat. Frontiers in Plant Science 2015, 6, 1012

118. Liu, H. Able, A.J.; Able, J.A. Water-deficit stress-responsive microRNAs and their targets in four durum wheat genotypes. Functional \& Integrative Genomics 2017, 17, 237-251 
119. Surdonja, K.; Eggert, K.;Hajirezaei, MR.;Harshavardhan, V.; Seiler, C.; von Wirén, N.;Sreenivasulu, N.; Kuhlmann, M. Increase of DNA methylation at the HvCKX2.1 promoter by terminal drought stress in barley. Epigenomes 2017, 1, 9.

120. Chwialkowska, K.;Nowakowska, U.;Mroziewicz, A.;Szarejko, I.; Kwasniewski, M. Water-deficiency conditions differently modulate the methylome of roots and leaves in barley (Hordeum vulgare L.). Journal of Experimental Botany 2016, 67, 1109-1121.

121. Konate, M.; Wilkinson, M.; Mayne, B.; Pederson, S.; Scott, E.; Berger, B.; Rodriguez Lopez, C. Salt stress induces non-CG methylation in coding regions of barley seedlings (Hordeum vulgare). Epigenomes 2018, 2, 12.

122. Mascher, M.; Gundlach, H.;Himmelbach, A. et al. A chromosome conformation capture ordered sequence of the barley genome. Nature 2017, 544, 427-433.

123. Temel, A.; Janack, B.; Humbeck, K. Drought stress-related physiological changes and histone modifications in barley primary leaves at HSP17 gene. Agronomy 2017, 7, doi:10.3390/agronomy7020043.

124. Zhu, N.; Cheng, S.; Liu, X.; Du, H.; Dai, M.; Zhou, DX.; Yang, W.; Zhao, Y. The R2R3-type MYB gene OsMYB91 has a function in coordinating plant growth and salt stress tolerance in rice. Plant Science 2015, 236, 146-156.

125. Yang, C.; Li, D.; Mao, D.; Liu, X.; Ji, C.; Li, X.; Zhao, X.; Cheng, Z.; Chen, C.; Zhu, L. Overexpression of microRNA319 impacts leaf morphogenesis and leads to enhanced cold tolerance in rice (Oryza sativa L.). Plant, Cell Environ. 2013, 36, 22072218, doi:10.1111/pce.12130.

126. Roy, D.; Paul, A.; Roy, A.; Ghosh, R.;Ganguly, P.; Chaudhuri, S. (Differential acetylation of histone H3 at the regulatory region of OsDREB1b facilitates chromatin remodeling and transcription activation during cold stress. PLoS ONE 2014, 9, e100343

127. Thiebaut, F.; Hemerly, A.S.; Ferreira, P.C.G. A role for epigenetic regulation in the adaptation and stress responses of nonmodel plants. Front. Plant Sci. 2019, 10, 1-7, doi:10.3389/fpls.2019.00246.

128. Hu, XL.; Lu, MH.; Li, CH. et al. Differential expression of proteins in maize roots in response to abscisic acid and drought. Acta Physiologiae Plantarum 2011, 33, 2437-2446.

129. Steward, N.; Ito, M.; Yamaguchi, Y.; Koizumi, N.; Sano, H. Periodic DNA methylation in maize nucleosomes and demethylation by environ- mental stress. The Journal of Biological Chemistry 2002, 277, 37741-37746.

130. Hu, X.; Wu, X.; Li, C.; Lu, M.; Liu, T.; Wang, Y.; Wang, W. Abscisic acid refines the synthesis of chloroplast proteins in maize (Zea mays) in response to drought and light. PLoS One 2012, 7, e49500.

131. Steward, N.;Kusano, T.; Sano, H. Expression of ZmMET1, a gene encoding a DNA methyltransferase from maize, is associated not only with DNA replication in actively proliferating cells, but also with altered DNA methylation status in coldstressed quiescent cells. Nuc Acids Res 2000, 28:3250-3259

132. Zhao, J.; Lu, Z.; Wang, L.; Jin, B. Plant Responses to Heat Stress: Physiology, Transcription, Noncoding RNAs, and Epigenetics. 2021.

133. Folsom, J.J.;Begcy, K.; Hao, X.; Wang, D.;Walia, H. Rice Fertilization- Independent Endosperm1 Regulates Seed Size under Heat Stress by Controlling Early. Plant Physiol. 2014, 165, 238-248

134. Liu, X.; Luo, M.; Zhang, W.; Zhao, J.; Zhang, J.; Wu, K. et al. Histone acetyltransferases in rice (Oryza sativa L.): phylogenetic analysis, subcellular localization and expression. BMC Plant Biol. 2012, 12, 14510.1186/1471-2229-12-145[PMC free article] [PubMed] [CrossRef] [Google Scholar]

135. Wang, W.; Qin, Q.; Sun, F.; Wang, Y.; Xu, D.; Li, Z.; Fu, B. Genome-wide differences in DNA methylation changes in two contrasting rice genotypes in response to drought conditions. Front. Plant Sci.2016, 7, 1-13, doi:10.3389/fpls.2016.01675.

136. Ni, Z.; Li, H.; Zhao, Y.; Peng, H.; Hu, Z.; Xin, M.; Sun, Q. ScienceDirect Genetic improvement of heat tolerance in wheat: Recent progress in understanding the underlying molecular mechanisms. Crop J. 2017, 6, 32-41, doi:10.1016/j.cj.2017.09.005.

137. Xin, M.; Wang, Y.; Yao, Y.; Xie, C.; Peng, H.; Ni, Z. et al. Diverse set of micro RNAs are responsive to powdery mildew infection and heat stress in wheat(Triticum aestivum L.). BMC Plant Biol. 2010, 10,123. doi:10.1186/1471-2229- 10-123

138. Sailaja, B.; Voleti, S.R.; Subrahmanyam, D.; Sarla, N.; Prasanth, V.V.; Bhadana, V. P. et al. Prediction and expression analysis of miRNAs associated with heat stress in Oryza sativa. Rice Science. 2014, 21, 3-12.doi:10.1016/S1672- 6308(13)60164-X

139. Kumar,R.R.; Pathak,H.; Sharma, S.K.; Kala,Y.K.; Nirjal, M.K.; Singh, G.P.; et al. Novel and conserved heat-responsive micro RNAs in wheat (Triticum aestivum L.). Funct.Integr.Genomics. 2014, doi: 10.1007/s10142-014-0421-0.

140. Kruszka, K.; Pacak, A.; Swida-Barteczka, A.; Nuc, P.; Alaba, S.; Wroblewska, Z.; et al. Transcriptionally and post transcriptionally regulated microRNAs in heat stress response in barley. J. Exp.Bot. 2014, 65, 6123- 6135.doi:10.1093/jxb/eru353

141. Wang, N.; Ku, LX.; Chen, YH.; Wang, W. Comparative proteomic ana- lysis of leaves between photoperiod-sensitive and photoperiod-insensitive maize inbred seedlings under long day treatments. Acta Physiologiae Plantarum 2015, $37,1705$.

142. Hou, H.; Zhao, L.; Zheng, X.; Gautam, M.; Yue, M.;Hou, J.; Chen, Z.; Wang, P.; Li, L. Dynamic changes in histone modification are associated with upregulation of Hsfand rRNA genes during heat stress in maize seedlings. Protoplasma 2019, $256,1245-1256$.

143. Zhang, K.; Yu, L.; Pang, X.; Cao, H.; Si, H.; Zang, J.; Xing, J.; and Dong, J.; In silico analysis of maize HDACs with an emphasis on their response to biotic and abiotic stresses. PeerJ, 2020, 8, p.e8539. 
144. Tsuji, H.; Saika, H.; Tsutsumi, N. et al. Dynamic and reversible changes in histone H3-Lys4 methylation and H3 acetylation occurring at submergence-inducible genes in rice. Plant Cell Physiol. 2006, 47, 995-1003

145. Gallo-franco, J. J.; Sosa, C. C.; Ghneim-herrera, T. Epigenetic Control of Plant Response to Heavy Metal Stress: A New View on Aluminum Tolerance. 2020, 11, doi:10.3389/fpls.2020.602625.

146. Chen, R.; Li, M.; Zhang, H.Y.; Duan, L.J.; Sun, X.J.; Jiang, Q.Y.; Zhang, H.; Hu, Z. Continuous salt stress-induced long noncoding RNAs and DNA methylation patterns in soybean roots. BMC Genomics 2019, 20, 730. [CrossRef] [PubMed]

147. Rizwan, M.; Ali, S.; Rehman, M.Z.; Rinklebe, J.; Tsang, D.C.W.; Bashir, A.; Maqbool, A.; Tack, F.M.G.; Ok, Y.S. Cadmium phytoremediation potential of Brassica crop species: A review. Sci. Total Environ. 2018, 631, 1175-1191. [CrossRef] [PubMed]

148. Wu, L.; Yu, J.; Shen, Q.; Huang, L.; Wu, D.; Zhang, G.Identification of microRNAs in response to aluminium stress in the roots of Tibetan wild barley and cultivated barley. BMC Genomics 2018, 19, 560. [CrossRef] [PubMed]

149. Zhang, H.; Chen, X.; Wang, C.; Xu, Z.; Wang, Y.; Liu, X.; Ji, W. Long non-coding genes implicated in responseto stripe rust pathogen stress in wheat (Triticum aestivum L.). Mol. Biol. Rep. 2013, 40, 6245-6253.

150. Shafiq, S.; Zeb, Q.; Ali, A.; Sajjad, Y.; Nazir, R.; Widemann, E.; Liu, L. Lead, cadmium and zinc phytotoxicity alter DNA methylation levels to confer heavy metal tolerance in wheat. Int. J. Mol. Sci. 2019, 20, 4676. [CrossRef]

151. Kashino-Fujii, M.; Yokosho, K.; Yamaji, N.; Yamane, M.; Saisho, D.; Sato, K.; Ma, J.F. Retrotransposon insertion and DNA methylation regulate aluminum tolerance in european barley accessions. Plant Physiol. 2018, 178, 716-727. [CrossRef]

152. Feng, SJ.; Liu, XS.; Tao, H.; Tan, SK.; Chu, SS.; Oono, Y. et al. Variation of DNA methylation patterns associated with gene expression in rice (Oryza sativa) exposed to cadmium. Plant Cell Environ. 2016, 39, 2629-49.

153. Ou, X.; Zhang, Y.; Xu, C.; Lin, X.; Zang, Q.; Zhuang, T.; Jiang, L. Transgenerational Inheritance of Modified DNA Methylation Patterns and Enhanced Tolerance Induced by Heavy Metal Stress in Rice (Oryza sativa L.). 2012, 7, doi:10.1371/journal.pone.0041143.

154. Erturk, F.A.; Agar, G.; Arslan, E. Analysis of genetic and epigenetic effects of maize seeds in response to heavy metal (Zn) stress. 2015, doi:10.1007/s11356-014-3886-4.

155. Shafiq, S.; Ali, A.; Sajjad, Y.; Zeb, Q.; Shahzad, M.; Khan, A.R.; Nazir, R.; Widemann, E. The Interplay between Toxic and Essential Metals for Their Uptake and Translocation Is Likely Governed by DNA Methylation and Histone Deacetylation in Maize. Int. J. Mol. Sci. 2020, 21.

156. Liu, X., Luo, M., Zhang, W., Zhao, J., Zhang, J., Wu, K. et al., 2012. Histone acetyl transferases in rice (Oryza sativa L.): phylogenetic analysis, subcellular localization and expression. BMC Plant Biol. 12, 145 10.1186/1471-2229-12-145 [PMC free arti-cle] [PubMed] [CrossRef] [Google Scholar]

157. Fang, C., Zhang, H., Wan, J., Wu, Y., Li, K., Jin, C., Chen, W., Wang, S., Wang, W. Zhang, H. et al., 2016. Control of Leaf Senescence by an MeOH-Jasmonates Cascade that Is Epigenetically Regulated by OsSRT1 in Rice. Mol. Plant. 2016, 9, 1366-1378, doi:https://doi.org/10.1016/j.molp. 07.007.

158. Zhou, L., Liu, Y., Liu, Z., Kong, D., Duan, M., Luo, L., 2010. Genome-wide identification and analysis of drought-responsive microRNAs in Oryza sativa. J. Exp. Bot. 61, 4157-4168. https://doi.org/10.1093/jxb/erq237

159. Mutum, RD., Balyan, SC., Kansal, S., Agarwal, P., Kumar, S., Kumar, M., Raghuvanshi, S., 2013. Evolution of variety-specific regulatory schema for expression of osa-miR408 in indica rice varieties under drought stress. The FEBS Journal 280 , 1717-1730.

160. Papaefthimiou, D., Tsaftaris, A.S., 2012. Characterization of a drought inducible trithorax-like H3K4 methyltransferase from barley. Biol Plant. 56, 683-692. https://doi.org/10.1007/s10535-012-0125-z

161. Kantar, M., Unver, T., Budak, H., 2010. Regulation of barley miRNAs upon dehydration stress correlated with target gene expression. Functional \& Integrative Genomics 10, 493-507.

162. Wang, Y., Li, H., Sun, Q., Yao, Y., 2016. Characterization of small RNAs derived from tRNAs, rRNAs and snoRNAs and their response to heat stress in wheat seedlings. PLoSOne 11, e0150933

163. Fei, Y.,Xue, Y., Du, P., Yang, S., 2017. Deng, X. Expression analysis and promoter methylation under osmotic and salinity stress of TaGAPC1 in wheat (Triticumaestivum L). Protoplasma, 254(2), pp.987-996.

164. Zhong, L., Xu, Y., Wang, J., 2009. DNA-methylation changes induced by salt stress in wheat Triticum aestivum. African J. Biotechnol. 8, 6201-6207.

165. Kong, L., Liu, Y., Wang, X., Chang, C., 2020. Insight into the role of epigenetic processes in abiotic and biotic stress response in wheat and barley. Int. J. Mol. Sci. 21, 1-15. https://doi.org/10.3390/ijms21041480

166. Duan, H., Li, J., Zhu, Y., Jia, W., Wang, H., Jiang, L., Zhou, Y., 2020. Responsive changes of DNA methylation in wheat (Triticum aestivum) under water deficit. Sci. Rep. 10, 1-8. https://doi.org/10.1038/s41598-020-64660-7. 
167. Tan, M., 2010. Analysis of DNA methylation of maize in response to osmotic and salt stress based on methylation-sensitive amplified polymorphism. Plant Physiol. Biochem. 48, 21-26. https://doi.org/https://doi.org/10.1016/j.plaphy.10.005

168. Forestan, C., Farinati, S., Zambelli, F., Pavesi, G., Rossi, V., Varotto, S., 2020. Epigenetic signatures of stress adaptation and flowering regulation in response to extended drought and recovery in Zea mays. Plant Cell Environ. 43, 55-75. https://doi.org/10.1111/pce.13660.

169. Wang, L., Fan, X., W, Pan., J. L, Huang., Z, B., Li, Y. Z., 2015. Physiological characterization of maize tolerance to low dose of aluminum, highlighted by promoted leaf growth. Planta 242, 1391-1403. doi: 10.1007/s00425-015- 2376-3

170. Wei, L., Zhang, D., Xiang, F., Zhang. Z., 2009. Differentially expressed miRNAs potentially involved in the regulation of defense mechanism to drought stress in maize seedlings. Int. J. Plant Sci. 170, 979-989. doi: 10.1086/605122 CrossRef Full Text | Google Scholar

171. Kantar, M., Lucas, SJ., Budak, H., 2011. miRNA expression patterns of Triticum dicoccoides in response to shock drought stress. Planta 233:471-484

172. Vendramin, S., Huang, J., Crisp, P.A., Madzima, T.F., McGinnis, K.M., 2020. Epigenetic regulation of ABA-induced transcriptional responses in maize. G3 Genes, Genomes, Genet. 10, 1727-1743. https://doi.org/10.1534/g3.119.400993.

173. Li, X., Jiang, Y., Ji, Z., Liu, Y., Zhang, Q., 2015. BRHIS 1 suppresses rice innate immunity through binding to monoubiquitinated H2A and H2B variants . EMBO Rep. 16, 1192-1202. https://doi.org/10.15252/embr.201440000

174. Akimoto, K., Katakami, H., Kim, HJ., Ogawa, E., Sano CM, et al., 2007. Epigenetic inheritance in rice plants. Ann Bot 100: 205-217.

175. Deng, Y., Zhai, K., Xie, Z., Yang, D., Zhu, X., Liu, J., Wang, X., Qin, P., Yang, Y., Zhang, G., and Li, Q., 2017. Epigenetic regulation of antagonistic receptors confers rice blast resistance with yield balance. Science, 355(6328), pp.962-965.

176. Li, T., Chen, X., Zhong, X., Zhao, Y., Liu, X., Zhou, S., Cheng, S., Zhou, D.X., 2013.Jumonji C domain protein JMJ705-mediated removal of histone $\mathrm{H} 3$ lysine 27 trimethylation is involved in defense-related gene activation in rice. The Plant Cell. 25(11), pp.4725-4736.

177. Li, Y., Xia, Q., Kou, H., Wang, D., Lin, X., Wu, Y., Xu, C., Xing, S., Liu, B., 2011. Induced Pib Expression and Resistance to Magnaporthegrisea are Compromised by Cytosine Demethylation at Critical Promoter Regions in Rice. J. Integr. Plant Biol. 53, 814-823. https://doi.org/10.1111/j.1744-7909.2011.01070.x

178. Hou, Y.,Wang, L., Wang, L., Liu, L., Li, L., Sun, L., Rao, Q., Zhang, J., Huang, S., 2015. JMJ704 positively regulates rice defense response against XanthomonasOryzaepv. Oryzae infection via reducing H3K4me2/3 associated with negative disease resistance regulators. BMC plant biology, 15 (1), p.286.

179. Demetriou, K., Kapazoglou, A., Tondelli, A., Francia, E., Stanca, M.A., Bladenopoulos, K.,Tsaftaris, A.S., 2009. Epigenetic chromatin modifiers in barley: I. Cloning, mapping and expression analysis of the plant specific HD2 family of histone deacetylases from barley, during seed development and after hormonal treatment. PhysiologiaPlantarum, 136, (3), pp.358-368.

180. Twamley, T., Ganey, M.,Feechan, A.,2019.A microbial fermentation mixture primes for resistance against powdery mildew in wheat. Front. Plant Sci. 10, 1241. [CrossRef]

181. Figueroa, M., Hammond-Kosack, K.E., Solomon, P.S., 2018. A review of wheat diseases-a field perspective. Mol. Plant Pathol. 19, 1523-1536. [CrossRef]

182. Sharma, C., Saripalli, G., Kumar, S., Gautam, T., Kumar, A., Rani, S., Jain, N., Prasad, P., Raghuvanshi, S., Jain, M., Sharma, J.B., Prabhu, K. V, Sharma, P.K., Balyan, H.S., Gupta, P.K., 2018. A study of transcriptome in leaf rust infected bread wheat involving seedling resistance gene Lr28. Funct. Plant Biol. 45, 1046-1064. https://doi.org/10.1071/FP17326

183. Shumayla; Shailesh, S.; Mehak, T.; Shivi, T.; Kashmir, S.; Santosh, K.U. Survey of high throughput RNA-Seq data reveals potential roles for lncRNAs during development and stress response in bread wheat. Front. Plant Sci. 2017, 8, 1019. [CrossRef] 
184. Cagirici, H.B.; Alptekin, B.; Budak, H. RNA sequencing and co-expressed long non-coding RNA in modern and wild wheats. Sci. Rep. 2017, 7, 10670. [CrossRef]

185. Huang, Y.; Li, L.; Smith, K.P.; Muehlbauer, G.J. Differential transcriptomic responses to Fusarium graminearum infection in two barley quantitative trait loci associated with Fusarium head blight resistance. BMC Genomics 2016, 17, 387. [CrossRef]

186. Unver, T.; Tombuloglu, H. Barley long non-coding RNAs (lncRNA) responsive to excess boron. Genomics 2019, 112, 19451955. [CrossRef]

187. Feng, H., Zhang, Q., Wang, Q. et al., 2013. Target of tae -miR408, a chemocyanin -like protein gene (TaCLP1), plays positive roles in wheat response to high -salinity, heavy cupric stress and stripe rust. Plant Molecular Biology 83, $433-443$.

188. Inal, B., Türkta, M., Eren, H.; et al., 2014 Genome -wide fungal stress responsive miRNA expression in wheat. Planta 240, $1287-1298$.

189. Sallam, N., Moussa, M., Yacout, M. and El-Seedy, A., 2020. Analysis of methylated genomic cytosines of maize inbred line W22 in response to drought stress. Cereal Research Communications, 48(4), pp.459-465.

190. Wang, C., Yang, Q., Wang, W., Li, Y., Guo, Y., Zhang, D., Ma, X., Song, W., Zhao, J., Xu, M., 2017. A transposon-directed epigenetic change in ZmCCT underlies quantitative resistance to Gibberella stalk rot in maize. New Phytol. 215, 15031515. https://doi.org/10.1111/nph.14688

191. Ding, B., del, Rosario., Bellizzi, M., Ning, Y., Meyers, B.C., Wang, G.L., 2012. HDT701, a histone H4 deacetylase, negatively regulates plant innate immunity by modulating histone $\mathrm{H} 4$ acetylation of defense-related genes in rice. The Plant Cell, 24(9), pp.3783-3794.

192. Liu, J., Zhi, P., Wang, X., Fan, Q., Chang, C., 2019. Wheat WD40-repeat protein TaHOS15 functions in a histone deacetylase complex to fine-tune defense responses to Blumeriagraminisf.sp. tritici. J. Exp. Bot. 70,255-268.

193. Zheng, M., Liu, X., Lin, J., Liu, X., Wang, Z., Xin, M., Yao, Y., Peng, H., Zhou, D.X., Ni, Z. et al., 2019. Histone acetyl transferase GCN5 contributes to cell wall integrity and salt stress tolerance by altering the expression of cellulose synthesis genes. Plant J. 97, 587-602.

194. Hu, Z., Song, N., Zheng, M., Liu, X., Liu, Z., Xing, J., Ma, J., Guo, W., Yao, Y., Peng, H., Xin, M., Zhou, D.-X., Ni, Z., Sun, Q., 2015. Histone acetyltransferase GCN5 is essential for heat stress-responsive gene activation and thermotolerance in Arabidopsis. Plant J. 84, 1178-1191. https://doi.org/10.1111/tpj.13076

195. Wang, X., Zhi, P., Fan, Q., Zhang, M., Chang, C.,2019. Wheat CHD3 protein TaCHR729 regulates the cuticular wax biosynthesis required for stimulating germination of Blumeriagraminisf.sp. tritici. J. Exp. Bot. 70,701-713.

196. Zhang, J., Wang, F., Liang, F., Zhang, Y., Ma, L., Wang, H. et al., 2018. Functional analysis of a pathogenesis-related thaumatin-like protein gene TaLr35PR5 from wheat induced by leaf rust fungus. BMC Plant Biology. $1876-87$. pmid:29728059. 